\title{
Infections, Vaccines and Autoimmunity: A Multiple Sclerosis Perspective
}

\author{
Dejan Jakimovski ${ }^{1, *(\mathbb{C})}$, Bianca Weinstock-Guttman ${ }^{2}{ }^{(1)}$, Murali Ramanathan ${ }^{3}$, \\ Michael G. Dwyer ${ }^{1}\left[\right.$ and Robert Zivadinov ${ }^{1,4}$ (D)
}

1 Buffalo Neuroimaging Analysis Center, Department of Neurology, University at Buffalo, State University of New York, Buffalo, NY 14203, USA; mgdwyer@bnac.net (M.G.D.); rzivadinov@bnac.net (R.Z.)

2 Jacobs MS Center, Department of Neurology, University at Buffalo, State University of New York, Buffalo, NY 14203, USA; bw8@buffalo.edu

3 School of Pharmaceutical Sciences, University at Buffalo, State University of New York, Buffalo, NY 14214, USA; murali@buffalo.edu

4 Center for Biomedical Imaging at Clinical Translational Science Institute, University at Buffalo, State University of New York, Buffalo, NY 14203, USA

* Correspondence: djakimovski@bnac.net

Received: 2 January 2020; Accepted: 24 January 2020; Published: 28 January 2020

\begin{abstract}
Background: Multiple sclerosis (MS) is a chronic neuroinflammatory and neurodegenerative disease that is associated with multiple environmental factors. Among suspected susceptibility events, studies have questioned the potential role of overt viral and bacterial infections, including the Epstein Bar virus (EBV) and human endogenous retroviruses (HERV). Furthermore, the fast development of immunomodulatory therapies further questions the efficacy of the standard immunization policies in MS patients. Topics reviewed: This narrative review will discuss the potential interplay between viral and bacterial infections and their treatment on MS susceptibility and disease progression. In addition, the review specifically discusses the interactions between MS pathophysiology and vaccination for hepatitis B, influenza, human papillomavirus, diphtheria, pertussis, and tetanus (DTP), and Bacillus Calmette-Guerin (BCG). Data regarding potential interaction between MS disease modifying treatment (DMT) and vaccine effectiveness is also reviewed. Moreover, HERV-targeted therapies such as GNbAC1 (temelimab), EBV-based vaccines for treatment of MS, and the current state regarding the development of T-cell and DNA vaccination are discussed. Lastly, a reviewing commentary on the recent 2019 American Academy of Neurology (AAN) practice recommendations regarding immunization and vaccine-preventable infections in the settings of MS is provided. Conclusion: There is currently no sufficient evidence to support associations between standard vaccination policies and increased risk of MS. MS patients treated with immunomodulatory therapies may have a lower benefit from viral and bacterial vaccination. Despite their historical underperformance, new efforts in creating MS-based vaccines are currently ongoing. MS vaccination programs follow the set back and slow recovery which is widely seen in other fields of medicine.
\end{abstract}

Keywords: multiple sclerosis; immunization; DNA-vaccine; T-cell vaccine; influenza; hepatitis B; Epstein Barr virus

\section{Introduction}

Multiple Sclerosis (MS) is a chronic inflammatory and neurodegenerative disease of the central nervous system (CNS) that significantly contributes towards neurological disability of the young and working population [1]. Although the etiology of MS still remains largely unknown, multiple environmental risk factors have been associated with greater disease susceptibility and disease 
progression [2]. In the mid-20th century, associations between the onset of several viral, bacterial, and helminthic infections with the prevalence of MS contributed towards creation of the "hygiene hypothesis" [3]. As with atopy, asthma, and other autoimmune diseases, MS can be partially described through the immunological framework of a balance between the type 1 immune response [T-helper 1 (Th1), driven by viral and bacterial infections that are highly active in autoimmune diseases) and type 2 immune response (Th2, driven by helminth infection and allergic diseases) [4]. As such, the hygiene hypothesis has been initially depicted by a virtually dichotomous relationship between high prevalence of Trichuris trichiura (common human helminth as surrogate marker for infections and community sanitation) and low prevalence of MS [5]. As additional support, greater exposure among siblings is also associated with a lower risk of MS, reinforcing a hygiene-based relationship which is already corroborated as a factor in atopy and asthma [6]. Therefore, it can be contemplated that insufficient immune activation early in life would lead to a less-developed and abnormal regulatory network, which can later allow aberrant immune responses towards self-antigens. On the other hand, a higher number of bacterial and viral infections during childhood that are accompanied with frequent use of antibiotics (all contributing towards Th1 response) are associated with greater risk of MS [7]. More so, the road towards the discovery of the first MS disease modifying treatment (DMT) - interferon- $\beta$ - was mainly driven by a viral hypothesis in mind [8]. That being said, most current MS DMTs (either small molecule or antibody-based medications) are focused on selective or general suppression of the immune system. MS-based medications would either attempt at depleting entire subset of immune cells (selective B-cell or both B and T-cell depletetors like ocrelizumab and alemtuzumab, respectively), sequester the pathological immune cells away from the CNS (natalizumab and sphingosine-phosphate receptor modulators), or inhibit the expansion of stimulated lymphocytes (teriflunomide and cladribine). [9,10]. However, none of these interventions target the underlying pathophysiology that still remains largely unknown.

Due to ongoing concerns regarding the role of viruses, bacteria, and their specific vaccinations in MS patients, the aim of this narrative review is to summarize such findings. Furthermore, we will discuss the attempts at developing vaccine-based therapies that would counter the immune imbalance present in MS. Lastly, we outline the potential effect of current MS immunomodulatory treatment on vaccination efficacy and comment on the latest 2019 American Academy of Neurology (AAN) immunization recommendations.

\section{Infections and Multiple Sclerosis}

\subsection{Bacterial Infections}

Recent studies have described potential associations between the rate of certain bacterial infections and prevalence of autoimmune or neurological diseases such as MS and Alzheimer's disease, respectively [11]. The mediators through which these factors interact include: changes in gut microbiota, Westernization of lifestyles, and improvements in sanitation. Helicobacter pylori is a highly motile Gram-negative bacteria that infects as much as $50 \%$ of the world's population and contributes towards gastric ulcers, chronic gastritis, and gastrointestinal cancers. Apart from the known associations between successful treatment of $H$. pylori and improvement in idiopathic thrombocytopenic purpura, studies have suggested that $H$. pylori infection can potentially influence the risk of MS [11,12]. The initial report of a potential protective association between higher rates of $H$. pylori infection in MS patients came from a Japanese study which analyzed 162 patients with either neuromyelitic optica (NMO) or MS [13]. The study showed that $H$. pylori seropositivity was significantly lower in MS patients when compared to the rate seen in NMO patients [13]. Furthermore, not only do MS patients have lower rates of $H$. pylori infection rates when compared to healthy controls, but $H$. pylori seropostivie MS patients also have lower disability scores [14]. Two recent meta-analyses including more than $1500 \mathrm{MS}$ cases and matched healthy controls have confirmed the findings of lower prevalence of $H$. pylori in MS patients [15,16]. Experimental MS mice studies have also shown that $H$. pylori 
infection contributes towards lower disease severity and significant reduction in the number of CD4 ${ }^{+}$ T-cells [17]. Interestingly, data have also shown that presence of a single filamentous bacterium in the small intestine can contribute to significant T-cell activation and induction of mural pro-inflammatory Th17 response targeting other pathogenic colonies [18]. Evolutionary, these symbiotic processes would maintain the balance of the gut bacterial colonies; however, the higher Th17 cytokine levels may also contribute to greater rate of systemic autoimmune diseases [18]. Additionally, studies describing the inverse association between a lower $H$. pylori infection rate and high prevalence of allergic diseases have also pointed towards a H. pylori-derived VacA toxin [19]. This toxin is responsible for shifting the balance towards Th1-based cytokine release, induced by release of IL-18 and conversion of CD4 $4^{+}$to regulatory $\mathrm{CD}^{2} 5^{+}$Foxp3 ${ }^{+}$T-cells [19].

On the other hand, several reports have shown a greater presence of antibodies towards Chlamydia pneumoniae in the cerebrospinal fluid (CSF) of MS patients when compared to controls [20]. Analysis of more than 120,000 members of California-based neurological practice has shown that presence of $C$. pneumoniae antibodies are significantly associated with a 70\% increase in future MS diagnosis; however, these findings are highly variable in the literature, with negative findings seen in other cohorts [21]. Later studies have also shown that C. pneumoniae can be seen in a vast range of neurological diseases [22]. Therefore, the high prevalence of $C$. pneumoniae can be associated with either some pathophysiological relevance or only a consequence of the general inability to fight-off such pathogens [22]. The induction of Th1-based inflammation due to bacterial infections can be highlighted by the exacerbation of MS symptoms due to acute urinary and/or respiratory tract infections [23]. Lastly, the effect of infections on the risk of MS can potentially be assessed through the proxy of antibiotic use. Although use of antibiotics specifically targeting C.pneumoniae do not influence the MS risk, studies have shown that overall use of antibiotics is associated with lower risk of MS [24,25]. However the trend of opposing findings continues, with other studies showing that the pairing of higher bacterial infection rates with greater antibiotic use are associated with increased risk of future MS diagnosis [7].

\subsection{Viral Infections and Virus-Targeted Treatments in Multiple Sclerosis}

Epstein-Barr virus (EBV) is a $\gamma$-herpesvirus and causative agent for infectious mononucleosis (IM) as well as lymphoid and epithelial malignancies. Furthermore, both asymptomatic EBV infection and IM have been also associated with an increase in MS susceptibility [26,27]. Despite the high EBV seropositivity of the general population ( 90\%), MS patients exhibit virtually omnipresent EBV reactivity [28]. In an analysis of 1,047 clinically isolated syndrome (CIS) patients, only $1(<0.01 \%)$ patient was deemed to be truly EBV seronegative [28]. The imminent increase in MS risk following an EBV seroconversion has been elegantly shown by a study which utilized serial blood samples derived from more than 8 million active duty military personnel [29]. During the follow-up period of 12 years, 315 soldiers were diagnosed with MS and later compared to randomly selected matched controls [29]. Ten (10) of these MS patients (3.3\%) were initially EBV seronegative and all of them had a change in serostatus prior to diagnosis [29]. The average time from the first seropositive test to MS diagnosis was 3.8 years [29]. On the other hand, only 35.7\% of the seronegative healthy controls exhibited EBV seroconversion [29]. Similar findings were seen in pediatric-onset MS cases, where EBV seropositivity was the only serological test which significantly differentiated children with MS and controls [30]. In that study, $86 \%$ of children with MS had evidence of previous EBV infection when compared to only $64 \%$ in the matched control group [30]. The findings of greater risk for MS in people with a high titer of EBV antibody levels were also corroborated, regardless of the ethnic/racial characteristics of the study population [31]. Interestingly, the study associations of lower MS risk in Hispanics born in low- or medium-income countries was deemed as non-significant after correcting for the EBV status [31]. Lastly, a recent Finnish maternity cohort of more than 800,000 women showed that high levels of EBV viral capsid (VCA) antibodies during the pregnancy period is associated with greater MS risk in their offspring [32]. This study further corroborated the role of EBV showing that mothers with high levels of Epstein-Barr nuclear antigen 1 (EBNA-1) antibody titer had more than 
3 times greater risk of future MS development [32]. In addition to increasing MS risk, higher EBV load as measured by the serum-based antibody titer has been associated with greater clinical and radiological MS pathology [33,34]. For example, a spike in immunological response towards EBV early antigens and towards EBV DNA is associated with concurrent disease activation, resulting in an MS relapse [33]. Moreover, higher anti-EBNA-1 levels are also associated with greater irreversible disability progression over mid-term follow-up period [35]. Lastly, the clinical outcomes coincide with associations of higher anti-EBNA-1 levels and greater MRI-derived rates of brain atrophy, more focal MS lesions, and more extensive cerebral demyelination [36,37].

Multiple experimental and histopathological studies have proposed potential mechanisms which can explain the interactions between EBV and the immunopathophysiolocal MS cascade. EBV infection significantly activates B-cells and upregulates their ability to present antigens [38]. Now as potent antigen-presenting cells, the infected B-cells will more efficiently process the relevant myelin autoantigen, attach it to their major histocompatibility complex II (MHC-II) receptors and cross-present them to the pathogenic $\mathrm{CD} 8^{+} \mathrm{T}$-cells $[38,39]$. In order to ensure survival, EBV also immortalizes the host B-cells, which in turn can continue to activate the effector T-cells. Although EBNA-1 molecule is not essential in the viral survival within the host B-cells, the presence of EBNA-1 induces up to a 100 times faster B-cell immortalization rate [40]. Lastly, EBV-infected B-cells employ multiple collateral activation pathways that can activate the aforementioned T-cells and enhance their IL-17 production [41]. High numbers of EBV-infected B-cells are repeatedly observed in MS white matter (WM) lesions, cortical lesions, and surrounding meninges [42,43]. The prevalent intracerebral EBV presence has been also demonstrated in a recent study where up to $93 \%$ of examined MS brain samples exhibit expression of EBV latent membrane protein 1 (LMP-1) and EBV-encoded RNA [44]. In terms of molecular mimicry, a recent study has shown partial complementary sequences and antibody cross-reactivity between EBNA-1 and newly proposed MS antigen of anoctamin 2 (CNS-based ion channel) [45]. A selected group of MS patients (approximately 32\%) do present with increased reactivity towards Anoctamin 2 and may represent an EBV-induced MS sub-phenotype [46]. All aforementioned findings provide multiple pathways that will aim at determining and isolating molecular targets in a potential vaccine-based EBV-targeted MS treatment.

Due to the complex nature of human herpesviruses, their life cycle, multitude of antigens being expressed, and the known oncogenic effects, developing a live vaccine towards EBV is a highly challenging proposition. Apart from a successful vaccination for $\alpha$-herpesvirus Varicella-Zoster virus (VZV) and vaccination for the veterinary and highly oncogenic Marek's disease virus (MDV), the use of live-attenuated oncogenic herpesviruses remains debated $[47,48]$. Therefore, multiple alternative vaccine candidates include targeting EBV-based glycoproteins (gp), EBV lytic proteins, and EBV latent proteins (summarized in Table 1) [49]. Furthermore, the advances in nanotechnology regarding assembling nanoparticles, scaffolds, and microneedles can allow better antigen delivery and increase the selected antigen circulation time [50].

Table 1. EBV-based molecular targets for development of EBV vaccine.

\begin{tabular}{|c|c|c|}
\hline EBV Phase & Antigen/Gene & Function \\
\hline \multirow{6}{*}{ Early - pre-latency } & Zta & Transcriptional regulator \\
\hline & & Activator of the switch from \\
\hline & Rta & latency to lytic cycle in B-cells \\
\hline & EBNA2 & $\begin{array}{l}\text { Activation and stimulation } \\
\text { of B-cell proliferation }\end{array}$ \\
\hline & EBHRF1 & $\begin{array}{l}\text { Prevents host cell apoptosis } \\
\text { and acts as Bcl-2 homolog }\end{array}$ \\
\hline & EBNA-LP & $\begin{array}{l}\text { EBNA2 co-activator and } \\
\text { upregulated LMP1 }\end{array}$ \\
\hline
\end{tabular}


Table 1. Cont.

\begin{tabular}{|c|c|c|}
\hline EBV Phase & Antigen/Gene & Function \\
\hline \multirow{3}{*}{ Latency phases } & LMP1 & $\begin{array}{l}\text { Acts as homologus CD40 } \\
\text { and active TNF receptor }\end{array}$ \\
\hline & LMP2A or $2 \mathrm{~B}$ & $\begin{array}{l}\text { Transmembrane proteins that } \\
\text { mimic activated B-cell receptor }\end{array}$ \\
\hline & EBNA1 & Impairs MHC-I antigen presentation \\
\hline Lytic & $\begin{array}{c}\text { Divided in immediate, } \\
\text { early and late lytic proteins }\end{array}$ & $\begin{array}{l}\text { Working towards the goal of } \\
\text { EBV-positive cell proliferation }\end{array}$ \\
\hline \multirow{3}{*}{ EBV glycoproteins } & gp350 & $\begin{array}{l}\text { Viral attachment to CD21 } \\
\text { or CD35 of B-cells }\end{array}$ \\
\hline & $\mathrm{gB}$ & Fusion protein \\
\hline & $\begin{array}{l}\text { gp42 } \\
\text { gHgL }\end{array}$ & Regulators of fusion \\
\hline
\end{tabular}

EBV - Epstein-Barr virus, Zta - BamHI Z Epstein-Barr replication activator coded by BZLF1 gene, Rta - R transactivator coded by BRLF1 gene, EBNA2 - Epstein-Barr nuclear antigen 2, which upregulates viral expression of latent genes (LMP1 and LMP2A/B) and host cell gene expression (coding CD21, and MYC), BHRF1 - apoptosis regulator BHRF1 coded by the homonymous gene, which prevents host cell death, EBNA-LP - Epstein-Barr nuclear antigen leader protein, LMP1 - latent membrane protein 1 coded by the homonymous gene, which activates immune response signaling pathways (NF-K-B family) and prevents apopotosis, TNF - tumor necrosis factor, LMP2A or 2B latent membrane proteins $2 \mathrm{~A}$ or $2 \mathrm{~B}$ acting as activated $\mathrm{B}$-cell receptor, $\mathrm{gp}$ - glycoprotein.

At this time, the biggest success towards developing an EBV-based vaccine has been by targeting gp350. This type I glycoprotein is crucial for the ability of EBV to enter the host B-cells by binding their CD21 or CD35 receptor. Both phase I and II human trials of gp350 vaccines have been carried out [51]. In a first phase I/II trial, $81 \mathrm{EBV}$ seronegative healthy volunteers were vaccinated with $0.5 \mathrm{~mL}$ recombinant gp350 at baseline, one month later, and six month booster doses [52]. A month after the last dose, all participants had significant anti-gp350 antibodies and no significant adverse events were reported. Although at a lower response rate, the EBV neutralization was most significant in the group vaccinated with adjuvanted gp350-specific vaccine $(60.9 \%$ of study participants achieved responses over the desired cut-off value) [52]. The same group also conducted a follow-up phase II double-blind, randomized, placebo-controlled (1:1 ratio) trial which enrolled $181 \mathrm{EBV}$ seronegative participants [53]. After two years of follow-up, 8 out of 91 placebo-controlled participants developed IM and only 2 out of 90 gp350-vaccinated developed mild cases of IM (78\% reduction in IM occurrence) [53]. It is important to note that the two vaccinated subjects developed the disease within their first six months within the trial and before the full three dose vaccination protocol was completed. However, the vaccination did not have any significant effect on the rate of asymptomatic EBV infection [53]. Therefore, one would assume that such vaccination with gp350 may result only in a decrease in the total EBV load and prevent progression into IM manifestation [53]. Given the vast variability and the long prodromal period from an EBV infection to the onset of MS, such EBV vaccine trials in MS populations are not feasible. However, until the successful development of a potent EBV vaccine, an alternative empirical study of EBV vaccination in first degree MS relatives can be hypothesized. With a 30 times greater rate of MS occurrence in first degree relatives when compared to unrelated populations, such intervention may potentially decrease the overall MS incidence [54].

Other potential targets for vaccine development include immediate and early EBV proteins that are expressed before the formation of the viral evasion capabilities. Therefore, both Zta and Rta immediate proteins (encoded by BZLF1 and BRLF1, respectively) are easily recognizable due to a uninhibited CD8 ${ }^{+}$T-cell response [55]. Furthermore, the early lytic proteins BMLF1 and BMRF1 can be detected by $\mathrm{CD}^{+}$T-cells as early as the first day of EBV infection [56]. Studies have examined the utility of BZLF1 vaccine in mice models of EBV-induced post-transplant lymphoproliferative disorder and showed successful induction T-cell immunity towards the infected tumor cells [57]. Lastly, recent evidence also show that the aforementioned latent proteins (EBNA) can be recognized by $\mathrm{CD} 8^{+}$and $\mathrm{CD}^{+}{ }^{+}$T-cells and prevent further expansion of EBV-infected B-cells [56]. In the wake of understanding 
the importance of B-cells in the MS pathophysiology, this type of vaccine intervention would potentially exert a therapeutic outcome [58].

Another potential EBV-targeted therapy could utilize EBV-primed CD8 ${ }^{+}$T-cells. Studies have shown that T-cells directed towards EBV antigens become increasingly exhausted, resulting in a gradual decrease of available EBV-specific $\mathrm{CD}^{+}$response [59]. This finding is further supported by associations of greater EBV replication rate, higher anti-EBNA-1 activity, and lower EBV-specific CD8 ${ }^{+}$cell count [59]. Mice studies have demonstrated that adoptive transfer of latent EBV antigen-specific CD8 ${ }^{+}$ T-cells (either towards BMLF1 or LMP2) can reduce the blood viremia and target lyrically-replicating EBV-transformed B-cells [60]. Furthermore, a histopathological study showed significant infiltration of MS lesions with cytotoxic CD8 ${ }^{+}$T-cells that can recognize latent and lytic EBV proteins $[61,62]$. In spite of concerns regarding the risk of allogenic viral-specific T-cells to recognize recipient HLA molecules, the use of adaptive transfer has generally not resulted in graft-versus-host disease [63]. An open-label phase I trial enrolled 10 progressive MS patients and infused them with escalating doses of in-vitro primed EBV-specific autologous T-cells [64]. The antigen-specific target in these T-cells was towards the aforementioned EBNA-1, LMP1, and LMP2A [64]. When compared to patients receiving low-activity T-cells, all six patients that received highly EBV-reactive T-cells exhibited some level of clinical improvement (3/6 patients exhibited decrease in disability scores) [64]. The lack of improvement in the remaining patients was attributed to substantial irreversible pathology at the time of enrollment [baseline Expanded Disability Status Scale (EDSS) scores of 8.0] [64]. However, it is unknown whether the presence of cerebral EBV-specific CD8 ${ }^{+} \mathrm{T}$-cells are contributing towards the local inflammatory processes and damaging the surrounding neuronal tissue or if they are part of a protective anti-viral mechanism. Before designing large-scale human trials, a greater understanding of the role of such EBV-targeting T-cells is warranted.

The increased expression of MS-associated retrovirus (MSRV) has been suggested as a potential link that would connect the EBV infection and its effect on the MS pathophysiological processes [65]. This virus belongs to the human endogenous retrovirus (HERV) family (later also interchangeably termed as HERV-W) which entered the mammalian germ line millions years ago via transmission through both Mendelian and non-Mendelian processes, and contributes towards $8 \%$ of the total human DNA [66]. Based on the specific tRNA involved in the HERV translation, these viruses are classified in several subfamilies including HERV-H, HERV-K, and HERV-W and all of them have been previously implicated in MS patients $[67,68]$. As such, increased expression levels of HERV-W viral proteins (either env, pol or gag) have been detected in MS-derived blood cells, the CSF, and brain tissues [68]. Up to $80 \%$ of MS patients present with significant serum levels of HERV-W env protein levels, compared to no such findings within healthy controls and very low prevalence within other neurological diseases [69]. Histopathological analysis also demonstrated significant HERV-W env immunoreactivity within active MS lesions, collocating HERV-W env to macrophages within the perivascular space [69]. Recent meta-analysis corroborated the findings by showing a strong association between MS and MSRV/HERV-W pol and env expression [68]. This was accompanied by a high odds ratio of 22.7 with no study inconsistencies and publication biases [68]. As a response towards the accumulating HERV-W pathophysiological data, development of antibodies that would target the env protein are currently ongoing [70]. GNbAC1 (later renamed as temelimab) is humanized IgG4 monoclonal antibody that binds the entire HERV-W env and inhibits the surface domain region, which has the ability to bind the Toll-like receptor 4 and induce pro-inflammatory cytokine release [71]. Apart from the desired target site, temelimab exhibits only one more off-target binding affinity towards MSRV-related protein encoded by chromosome 7 and expressed in the human placenta termed enverin [70]. Encouraged by the good safety profile and linear pharmacokinetics seen in phase I, this antibody has been further tested in two phase IIa and IIb MS trials [72]. In addition to a decrease in MSRVenv and MSRVpol transcripts levels, the group on the highest dose of $18 \mathrm{mg} / \mathrm{kg} \mathrm{GNbAC1demonstrated} \mathrm{2-year} \mathrm{significant}$ $63 \%$ reduction in new T1-black holes, significant reduction of brain atrophy ranging from $72 \%$ reduction in the thalamus to $29 \%$ in the whole brain volume (CHANGE-MS; NCT02782858). Interestingly, the 
study did not show any effect on the number of gadolinium-enhancing lesions. These neuroprotective findings were further corroborated in a 96 weeks extension trial (ANGEL-MS; NCT03239860), which demonstrated sustained whole brain atrophy reduction effects of $\sim 40 \%$ in the $18 \mathrm{mg} / \mathrm{kg} \mathrm{GNbAC1}$ study group.

Another potential mechanism by which $\mathrm{GNbAC1}$ can exert its beneficial effect is by uncoupling the process of MSRVenv-mediated reduction in oligodendrocyte differentiation [73]. The presence of MSRVenv proteins in proximity of oligodendrocyte progenitor cells result in increased cell stress response, formation of 3-nitrotyrosine, and lower myelin basic protein expression [73]. Potentially remyelinating clinical effects can also be seen within the phase IIb extension trial, where the $18 \mathrm{mg} / \mathrm{kg}$ GNbAC1study group demonstrated improvement within the magnetization transfer ratio signal of the normal-appearing WM (MRI-based marker for myelination). In conclusion, the effectiveness of anti-MSRVenv antibody strengthens the potential role of HERVs in MS.

\section{Vaccines and Multiple Sclerosis}

\subsection{Vaccines and Risk of MS Onset and MS Relapses}

The core of any post-marketing vaccine safety surveillance includes monitoring for adverse events following immunization (AEFI). Events that occur at a greater rate than the normally expected background prevalence raise new concerns and trigger additional investigations. Classic neurological examples of such vaccine safety analysis involve Guillain-Barre occurrence after pandemic influenza immunizations [74]. The interest of a vaccine-induced MS onset spiked during a large French hepatitis B vaccination campaign which occurred from 1995 through 1997. Multiple reported MS cases developing weeks following hepatitis B vaccination, together with some preliminary positive analyses, resulted in a complete suspension of the country-wide vaccination program [75]. In response, multiple international efforts followed to refute the proposed association [76,77]. A US-based nested case-control study was not able to find evidence of increased risk of MS and hepatitis B vaccination [76]. A study from the Canadian British Columbia also investigated the rate of adolescent onset of MS or other demyelinating diseases before and after the initiation of hepatitis B vaccination and found no sufficient evidence for establishing such causative link [77]. Furthermore, a French-based study revisited the rate of CNS demyelination in children vaccinated during and after the questionable time period (1994-2003) and showed no significant increase in disease onset within the pre-established risk period of three years post-vaccination [78]. However, when the study restricted the analysis to include only subjects that were fully compliant with the vaccination guidelines, exposure to the particular Engerix B vaccine was associated with a 2.4-fold greater odds ratio for future confirmed MS diagnosis [78]. The same study group also attempted to determine whether hepatitis B or tetanus vaccination increased the rate of a second relapse in children with a previously-diagnosed demyelinating CNS disease [79]. Although it concluded that hepatitis B and tetanus vaccination do not increase the relapse rate, the study was highly underpowered, with only 33 pediatric MS patients receiving hepatitis B vaccine, of which only six of them actually relapsed within the three year period [79]. Similar analyses expanded the study scope to include influenza vaccination and also showed no significant increase in relapses within the last two months post-vaccination [80]. A recent meta-regression analysis of all studies pertaining to the risk of MS development after hepatitis B vaccination has corroborated the lack of such an association [81].

This topic was recently revisited by a nested case-control study which analyzed the risk of an acquired CNS demyelinating disease occurring within three years of hepatitis B or human papillomavirus (HPV) vaccination [82]. Although the study refuted such associations, vaccination within 30 days was correlated with a 2.3-fold greater occurrence of CNS demyelinating disease, particularly seen within younger populations ( $<50$ years old) [82]. Among cases that developed CNS demyelinating disease, the most implicated vaccines were influenza and diphtheria, tetanus and pertussis (DTP) [82]. Due to the fact that 3 out of the 24 cases had either a family history of MS, previous radiologically isolated syndrome (RIS) diagnosis, or other systemic autoimmune diseases, the authors 
concluded that the vaccination only resulted in acceleration towards symptomatic demyelination in preexisting disease circumstances [82]. Given the natural history progression in such circumstances, the phenotypical presentation and follow-up relapse could have been potentially anticipated. The risk of MS and other demyelinating disease after HPV vaccination was further investigated in two large Danish and Swedish registries which encompassed almost four million females and two million doses of quadrivalent HPV vaccine spanning over a follow-up period of seven years [83]. Comparison between the unvaccinated and 2-year post-vaccination periods showed no increased risk of MS after the HPV vaccination [83]. Furthermore, administrative claims data from the largest US medical insurance subsidiary showed no increased risk of optic neuritis development within 60 days after HPV vaccination [84]. Recent meta-analysis included six different HPV studies and was not able to determine any increase in the risk for MS [85]. Smaller numbers of studies have examined the risk of MS after diphtheria, tetanus, and pertussis vaccination and have not found any associations [86-88].

Despite some reports suggesting an increased rate of exacerbations following an influenza immunization [89], a larger body of evidence show that such associations do not exist [80,90]. For example, a double-blind, placebo-controlled study randomized $104 \mathrm{MS}$ patients to either standard influenza immunization or placebo injection and demonstrated no increased relapse rate within the 6-month follow-up period [91]. Furthermore, when compared to the placebo, the time to relapse was significantly longer in the immunized MS patients [91]. More importantly, vaccinating MS patients with seasonal influenza vaccine can further limit the deleterious effects derived from fully manifesting flu. Experimental studies have shown that active influenza infection can trigger glial activation, increased T-cell, and neutrophil cerebral trafficking, and contribute towards more severe MS exacerbations [92].

In contrast, some studies have discussed a potential protective effect of Bacille Calmette-Guerin (BCG) immunization on the risk and severity of MS [93,94]. In a small MS pilot trial, MRI-derived lesion activity was determined before and after $12 \mathrm{MS}$ patients were injected with a single dose of a BCG vaccine [93]. When compared to the study run-in period, the vaccination resulted with $51 \%$ reduction in contrast-enhancing and 57\% reduction in active T2 lesions, respectively [93]. A consecutive double-blind trial utilized 73 CIS patients which were randomized to either BCG vaccination group or placebo and were followed by monthly MRIs for six months. In a second, preplanned extension period, all MS patients continued with IFN- $\beta$ treatment [94]. During the first 6-month period, BCG vaccinated patients had significantly lower amounts of contrast-enhancing lesions (45.9\% relative risk reduction), less new enlarging T2 lesions (63.6\% relative risk reduction), and less new T1-based black holes (85.1\% relative risk reduction) [94]. Moreover, the reduced amount of MRI activity remained low in the BCG+DMT extension study arm [94]. When compared to placebo+DMT, the BCG+DMT group had a significantly lower risk of fulfilling the clinically definite MS criteria during the 5-years follow-up [94]. A similarly designed study is currently investigating the effect of BCG vaccination in RIS patients. (NCT03888924) An interesting experimental study has recently showed significant differences in mycobacterial responses between MS and NMO patients [95]. The MS patients showed a significantly greater immune response towards mycobacterium avium and a significantly low rate of response towards the mycobacterium bovis (comparable to BCG), findings which were the opposite of those in NMO [95]. These differences may be explained by different types of transmission (M. avium through gut vs. $M$. bovis through skin) and the higher probability of $M$. avium to produce an antigen-specific humoral response [96]. In fact, $M$. avium infection in mice MS models results in early disease onset and more severe disease progression [97]. It is currently unknown through which processes BCG vaccination may interact and alleviate the MS pathophysiology.

\subsection{Vaccine Effectiveness in Multiple Sclerosis}

Due to the increasing use of immunosuppressive medications as standard MS care, considerations regarding the effectiveness of vaccination protocols would naturally arise. A variation of MS case-controlled or observational studies have examined the effectiveness of influenza vaccine and/or vaccination towards capsular bacteria. However, before reviewing the effect of the immunomodulatory 
treatments, it is important to mention that only a few studies have shown a sufficient vaccination effect in untreated MS patients [98]. The Rebif-Influenza Vaccine Study was one of the first designed trials that would investigate the effect of IFN- $\beta$ use on vaccinations [99]. The primary end point was achieved if the hemagglutination inhibition titers of the vaccinated patients reached $\geq 40$, indicating seroprotection [99]. Out of $163 \mathrm{MS}$ patients that received the influenza vaccine, 53\% were treated with IFN- $\beta-1 \mathrm{a}$ and $47 \%$ were not on DMT [99]. No differences were noted, where $93 \%$ of IFN- $\beta$-treated and $90.9 \%$ of non-treated MS patients achieved good post-vaccination hemagglutination inhibition titers [99]. During the 28-day period, no MS patient experienced a relapse [99]. A more recent and smaller IFN- $\beta$ study corroborated the unhindered ability of these MS patients to mount a sufficient anti-influenza response [100]. An equivalent study design was deployed to examine the potential effect of teriflunomide on the response to trivalent influenza vaccine (TERIVA study) [101]. A high percentage of IFN- $\beta$-treated controls and both the $7 \mathrm{mg}$ and $14 \mathrm{mg}$ teriflunomide groups already had baseline high antibody titers towards $\mathrm{H} 1 \mathrm{~N} 1$ (88.4\%, 82.5\%, and 87.2\%, respectively) and approximately half of the patients had high baseline protection towards the B strain $(53.5 \%, 70 \%$, and $69.2 \% \%$ ) and H3N2 (48.8\%,55\%, and 53.8\%, respectively) [101]. After the vaccination protocol, the $14 \mathrm{mg}$ teriflunomide group resulted in a lower percentage of patients with sufficient H3N2 antibody titer when compared to the $7 \mathrm{mg}$ teriflunomide and IFN- $\beta$ control group (76.9\% vs. 97.4\% and 97.4\%) [101]. That being said, all groups achieved the $70 \%$ proportion required by the European Criteria for Efficacy of Influenza Vaccination. In a randomized placebo-controlled trial, $138 \mathrm{MS}$ patients were allocated to either $0.5 \mathrm{mg}$ fingolimod or placebo groups (2:1 ratio) and six weeks later were vaccinated with the seasonal influenza vaccine [102]. Three weeks later, the responder rate for the influenza vaccine was $54 \%$ for the fingolimod-treated vs $84 \%$ for the placebo MS patients [102]. Furthermore, an even greater difference was seen at the 6-week follow-up (43\% vs. 75\% for fingolimod-treated and placebo MS groups, respectively) [102]. Although the differences between the groups were smaller and non-significant for an antigen-recall vaccination (tetanus toxoid booster dose), the fingolimod group did have a numerically lower proportion of responders [102]. A previous study with daclizumab, now withdrawn from the DMT market, also reported sufficient vaccinator response in an open-label single-arm extension study (termed SELECTED) [103]. The reported rate of seroconversion (from $<10$ hemagglutination inhibition titer to $\geq 40$ ) was $69 \%$ for $\mathrm{H} 1 \mathrm{~N} 1,69 \%$ for $\mathrm{H} 3 \mathrm{~N} 2$, and $44 \%$ for $\mathrm{B}$ influenza strain [103]. Although the study had a sufficient ratio of responders as per EMA/FDA criteria, the lack of control arm limits the ability in deriving final conclusions. [103]. Other open-label, observational studies have utilized mixed patient populations which were treated with different DMTs and determined the overall influenza efficacy. For example, in a study of 102 MS patients, only $28.6 \%$ of natalizumab-treated cases achieved seroprotection towards H3N2, whereas the entire cohort had an average seroprotection rate of $72.5 \%$ [104]. Furthermore, the use of DMT was the only statistical predictor of not achieving seroprotection [104]. Interestingly, MS patients previously treated with other DMTs before their current therapy had significantly lower seroprotection when compared to those that were still on their first-choice medication (58\% vs. $86 \%$ response rates) [104]. Lastly, the total cohort did not develop sufficient herd immunity of $>40 \%$ seroprotected for influenza B strain [104]. During the 2009 influenza pandemic, a total of 113 MS patients and 215 controls were vaccinated with H1N1 swine flu vaccine [105]. When compared to the $43.5 \%$ response rate in controls, only MS patients treated with IFN- $\beta$ achieved significant response (44.4\% with HI titer of $>40$ ) [105]. On the other hand, a significantly lower response was seen in MS patients on glatiramer acetate (21.6\%) or natalizumab $(23.5 \%)$, and none of the MS patients on mitoxantrone developed protection towards influenza (0\%) [105]. The same Author group provided a repeated study of a seasonal influenza vaccination where only MS patients on IFN- $\beta$, glatiramer acetate and non-treated MS patients showed comparable protection rates to the healthy controls [106]. On the other hand, both fingolimod and natalizumab-treated patients had significantly reduced protection rates [106]. Taken together, real-world observational studies do demonstrate lower rates of seroprotection when compared to the few aforementioned blinded vaccination trials. 
The remaining studies utilize a range of vaccines that would test T-cell dependent recall response (tetanus-diphtheria toxoid vaccine), T-cell-independent humoral response (pneumococcal vaccine) and T-cell-dependent neoantigen response (meningococcal vaccine). An IFN- $\beta$-controlled study examined the effectiveness of vaccination in MS patients treated with dimethyl fumarate (DMF) [107]. There were no significant differences in T-cell-dependent recall response (both $68 \%$ of DMF-treated patients and $73 \%$ of IFN- $\beta$-treated patients had $\geq 2$-fold increase in IgG), lower but non-significant T-cell independent humoral response (66\% of DMF-treated vs. $79 \%$ IFN- $\beta$-treated) and no differences in the response towards neoantigen, with $53 \%$ of both DMF- and IFN- $\beta$-treated MS patients developing immunity towards meningococcal C [107]. A similar vaccine design was employed for a pilot study in 25 MS patients treated with alemtuzumab, which were compared to literature controls [108]. The T-cell dependent recall response was not assessed due to $100 \%$ pre-vaccination titer above the upper detection levels of the assay. On the other hand, the patients demonstrated a significant change from $13 \%$ to $91 \%$, achieving seroprotection towards meningitis C [108]. Comparable to literature controls, $73 \%$ and $95 \%$ of alemtuzumab-treated patients demonstrated a 2 -fold increase in antibodies towards pneumococcal vaccine serotypes 3 and 8, respectively [108]. It is important to note that only 2 out of 5 patients that received their vaccination within six months of alemutuzumab treatment did achieve a significant response [108].

Despite the fact that there are no MS studies that analyze vaccine response in settings of B-cell depleting therapies, such inferences can be derived from rheumatoid arthritis (RA) or NMO patients [109]. A study of 43 rituximab-treated RA patients showed diminished rates of achieving satisfactory levels of hemagglutination inhibition titer towards H3N2 (21\% vs. $67 \%$ of matched controls) [110]. Furthermore, only $14 \%$ of rituximab-treated RA patients achieved immune response towards more than one antigen from the trivalent vaccine [110]. The seroprotection in these cases was not influenced by the additional methotrexate or prednisone treatment [110]. A similar lack of response has been shown in rituximab-treated lymphoma patients, where in comparison to $82 \%$ response rate in the control group, none of the 62 patients achieved sufficient vaccine efficacy [111]. Lastly, NMO patients receiving rituximab failed to mount sufficient titer of hemagglutination inhibition antibodies when compared to NMO patients treated with azathioprine or when compared to healthy controls [112]. However, these NMO patients did retain good T-cell-dependent recall response towards previously formed immunity [112]. Based on these studies, MS patients treated with B-cell depleting therapies may exhibit impaired vaccine response to influenza vaccination. A recent open-label, randomized Phase $\mathrm{IIIb}$ trial recruited $102 \mathrm{MS}$ patients that were randomized either to ocrelizumab or no DMT group and assessed the humoral responses towards multiple vaccination protocols (VELOCE trial, NCT02545868). Patients treated with ocrelizumab had an attenuated humoral response when compared to the control group towards the tetanus vaccine ( $23.9 \%$ vs. $54.5 \%)$, pneumococcal vaccine $(71.6 \%$ vs. $100 \%)$, and influenza vaccine (ranging from $55.6 \%$ to $80 \%$ in ocrelizumab-treated patients vs. $75 \%$ to $97 \%$ response in the control group, for 2015/2016 and 2016/2017 seasons, respectively).

\subsection{Vaccines as Treatment for Multiple Sclerosis}

Multiple attempts at developing MS-based vaccines have been previously explored and tested both in mice models and human subjects. Due to the vast number of studies, we will utilize a non-exhaustive list which will assist in demonstrating the variety of vaccine-targeted disease mechanisms. In the later 1990s, the initial increased interest in vaccination for MS led to multiple Phase I/II MS trials. One example showed that the commonly attempted T-cell vaccination principle does not deviate much from the typical vaccination paradigm. After retrieval and sorting of myelin-specific autoreactive T-cells from MS patient's serum, the T-cells undergo in-vitro attenuation before being re-infused into the patients. The immune system therefore recognizes this attenuated agent (in this case myelin-specific T-cell) and mounts an immune response towards such circulating pathogenic T-cells.

Several small pilot studies preceded the patent acquisition and development of T-cell vaccination $[113,114]$. The first reported study utilized myelin-basic protein (MBP)-reactive T-cell 
lines derived from each subject, irradiated and re-infused back [113]. After the second inoculation, the patients demonstrated a significant decline in circulating MBP-reactive T-cells [113]. The study also suggested a potential induction of separate anti-clonotypic T-cells, which probably were able to recognize the variable region of the T-cell receptor and cause the depletion [113]. Two years later, a longitudinal study vaccinated five patients with RRMS and three with SPMS with autologous MBP-reactive and attenuated T-cells. The vaccinated patients demonstrated only an $8 \%$ increase in MRI-derived lesion volume, when compared to 39.5\% in matched controls [114]. Another study utilized four SPMS patients which were inoculated every three months during a two year period with approximately 40 million bovine myelin-reactive and later attenuated T-cells per injection [115]. After the second cycle, a significant decrease in myelin-reactive and IFN- $\gamma$-producing T-cells was noted [115]. The cytotoxic effect was controlled by measuring the number of tetanus toxoid-reactive T-cells which remained stable [115]. However, there were no clinical effects, with two patients that remained stable, one that improved and one that worsened over the follow-up period [115]. After the aforementioned preliminary studies, an autoreactive attenuated T-cell vaccine named Tovaxin ${ }^{\circledR}$ (later renamed as Tcelna ${ }^{\circledR}$, Opexa Therapeutics) was tested in both Phase I/II and Phase IIb studies $[116,117]$. In the first smaller trial, isolated autoreactive T-cells reactive towards three major myelin antigens [myelin basic protein (MBP), proteolipid protein (PLP), and myelin oligodendrocyte glycoprotein (MOG)] were attenuated by $\gamma$-irradiation and administered back in 4 doses spanning over 20 week period [116]. Sixteen MS patients that had previously failed on other immunomodulatory medications were enrolled, and personalized vaccines were developed based on the peptide-specific T-cell reactivity [116]. The vaccination resulted in an early and significant $92.4 \%$ reduction in circulating myelin-specific T-cells, with a sustained $64.8 \%$ effect at week 52 [116]. The relapse rate analysis demonstrated a $85 \%$ decrease in the annual relapse rate; however, a significant part of the reduction could also be explained by regression to the mean. Disability analysis at the last follow-up visit at week 52 showed varied results [116]. Equal sets of $18.2 \%$ of MS patients showed either clinical improvement or worsening, respectively, whereas the remaining $63.6 \%$ remained stable [116]. The study showed only a mild to moderate adverse effect and no effect on the MRI-based contrast-enhancing lesions [116]. The second placebo-controlled, double-blind Phase IIb study was set to determine the efficacy of Tovaxin ${ }^{\circledR}$ in Early Relapsing Multiple Sclerosis (TERMS study) and randomized 100 patients into treatment arm and 50 patients in placebo (2:1 ratio) [117]. A secondary post-hoc analysis included only 50 patients that had at least two or more relapses in the year preceding the study entry [117]. Analysis of the overall intent-to-treat group showed no significant clinical nor radiographic differences between the Tovaxin ${ }^{\circledR}$-treated and placebo MS patients [117]. Within the MS group with annualized baseline relapse rate $>1$, Tovaxin ${ }^{\circledR}$-treated patients had a trend of $56 \%$ reduction in relapses and a significant improvement in longitudinal EDSS scores [117]. The fact that the recruited MS patients were not DMT-naïve may have substantially reduced our ability to derive final conclusions. A rebranded Tcelna ${ }^{\circledR}$ (Imilecleucel-T) drug was later further investigated in an additional Phase II trial in 183 SPMS patients, but the study did not meet the predefined primary end-point of lowering the brain atrophy nor the secondary endpoint of reducing the disability progression (NCT01684761).

Early experimental studies have shown that encephalitogenic T-cells express specific T-cell receptor (TCR) sequences within the complementary determining regions 2 and 3 (CDR2/CDR3) that can be recognized and targeted [118]. As such, one of the first proof-of-concept double-blind, placebo-controlled trials utilized vaccination with peptides specific towards V $\beta 5.2$ expressing T-cells [119]. A group of 23 progressive MS patients were randomized in either 12-month vaccine treatment (100 $\mu \mathrm{g}$ weekly for four weeks, followed by monthly single doses) or placebo [119]. Six out of 17 vaccinated patients demonstrated an induced T-cell response towards the V $\beta 5.2$ TCR compared to none of the placebo group [119]. Comparable to the experimental data, the responders also showed significant and persistent decrease in MBP-specific T-cells [119]. On the other hand, the non-responders and placebo group demonstrated an increase in MBP-specific T-cells [119]. There was a significant correlation between the frequency of MBP-specific T-cells and clinical outcomes [119]. In particular, 
patients with an increase in MBP-specific T-cells had disability progression, whereas the vaccine responders improved or remained clinically stable [119].

A Phase I/II trial tested trivalent TCR CDR2 peptide vaccine (containing BV5S2, BV6S5 and BV13S1 sequences) in 37 MS patients [120]. Immunological response to the vaccine was achieved in $94 \%$ of the adjuvant-vaccinated group, $14 \%$ in an non-adjuvant group, and $16 \%$ in the adjuvant-only group [120]. Responders to the vaccine had a significant induction of TCR-directed T-cells and each peptide acted as an individual immunogen [120]. During the 24-week study period, there were no clinical nor radiological differences between the responders and non-responders to the vaccination [120]. This was followed by an open-label single-arm study which recruited 23 MS patients (14 RRMS and 13 PMS) and assessed the mechanisms of action through which the mixture of the aforementioned three TCR-based peptides exhibited their effect [121]. After the vaccination, the patients had a significant increase in TCR-reactive T-cells, an effect that by the end of the trial returned back to the initial starting levels [121]. The vaccination also produced increase in IL-10-secreating T-cells and upregulated expression of FoxP3 within the regulatory T-cells [121]. Lastly, the vaccination also produced an expanded immunoregulatory network that spanned beyond the three TCR peptides and suppressed reactivity towards other neuroantigens [121]. Due to the financial problems of the original developer, no further development of NeuroVax ${ }^{\circledR}$ is planned. Recently, the patent for the TCR peptide vaccine has been acquired by another pharmaceutical company (Immune Response BioPharma) which already initiated a Phase II double-blind, placebo-controlled SPMS study (NCT02149706). In 2014 FDA has designated NeuroVax ${ }^{\circledR}$ with Pediatric Orphan Designation and Fast Track Designation for SPMS; however, no progress has been recently reported.

In light of the success seen in allergology, MS studies have also tried to induce antigen-specific tolerance by administration of analog peptides to the T-cell receptor (also termed as peptide vaccination). The form and preparation of the peptide varied from full length MBP, PLP, or MOG sequences, utilizing modified liposome packaging, and use of antigen-processing-independent epitopes (apitopes).

A double-blind, placebo-controlled RRMS study utilized an adhesive patch containing mixture of three different myelin peptides (PLP139-151, MOG35-55 and MBP85-99) over a period of one year [122]. Ten patients were randomly allocated to a placebo, 14 patients were treated with skin patch containing $1 \mathrm{mg}$ of each peptide and four received a patch containing $10 \mathrm{mg}$ of each peptide [122]. The transdermal application of myelin peptides resulted with formation of local and regional myelin-specific antigen-presenting cells [122]. The immunized patients also exhibited a significant decrease of myelin-specific CD4+ T-cells, greater levels of IL-10, and decreased levels of IFN- $\gamma$ and TGF- $\beta$ [122]. These changes were corroborated by significant clinical and radiological findings [122]. Both groups of RRMS patients treated with the $1 \mathrm{mg}$ or $10 \mathrm{mg}$ skin patch had significantly lower annualized relapse rate when compared to the placebo [123]. Only 19\% of the 1 mg-treated RRMS patients had worsening in the EDSS scores when compared to $70 \%$ of the placebo [123]. Over the 12-month study period, patients in the $1 \mathrm{mg}$ group showed a $19.7 \%$ decrease in T2 lesion volume and a $14.1 \%$ decrease in T2 lesion volume, whereas the placebo group had an increase of $25.4 \%$ and $61.2 \%$ in T2 and T1 lesion volumes, respectively [123]. Moreover, the $1 \mathrm{mg}$ group also had a $66.5 \%$ reduction in the cumulative number of contrast-enhancing lesion [123]. Apart from mild skin reactions, no adverse events were noted [123]. The potential immunomodulatory efficacy, lower risk profile, and ease of administration makes such intervention an attractive treatment option. When compared to the current MS disease modifying treatments, the desensitization process towards myelin peptides does not significantly impact the entirety of the immune system and does not result in states of immune vulnerability.

In order to improve the desensitization, MBP peptides can be packaged in mannosylated liposomes which enhance their ability to bind with the dendritic CD206 receptor [124]. As such, the antigen-presenting cells can more efficiently activate regulatory T-cells and promote an anti-inflammatory effect [124]. A second synthetically produced mixture of four short MBP apitopes into one peptide vaccine named ATX-MS-1467 has been tested [125]. The preclinical MS mice models showed a significant dose-dependent effect in decreasing the mean overall disability, the peak disability 
scores and shortened the disease duration [125]. In a first Phase I trial, six SPMS patients received escalating doses up to $800 \mathrm{mg}$ of ATX-MS-1467 and tolerated the medication relatively well [125]. No significant clinical effects were seen with a decrease in T-cell proliferative response towards MBP and a trend towards higher IL-10 gene expression [125]. Two additional Phase $\mathrm{Ib}$ and Phase IIa trials were recently conducted [126]. The first study had a primary outcome to determine the best mode of administration (intradermal vs. subcutaneous injections) and a secondary outcome of assessing the effect on MRI-detected contrast-enhancing lesions [126]. Based on the Phase $\mathrm{Ib}$ results, a faster intradermal 4-week titration period starting from $50 \mu \mathrm{g}$ on day 1, $200 \mu \mathrm{g}$ on day 15, and $800 \mu \mathrm{g}$ on day 29 was utilized. This was followed by biweekly $800 \mu \mathrm{g}$ injections for 16 weeks and an additional 16 weeks extension follow-up period [126]. Phase $\mathrm{Ib}$ study showed a significant $73 \%$ decrease in contrast-enhancing lesions (during 0-16 weeks) with a return to baseline values by the end of the observational period [126]. In comparison, the Phase IIa study showed a lower but significant decrease in contrast-enhancing lesions, an effect that persisted throughout the end of the observational period [126]. There were no changes in the predetermined disability outcomes with only a significant post-hoc finding of cognitive improvement [126]. Apitope ${ }^{\circledR}$ has already announced plans for a Phase IIb, placebo-controlled, ATX-MS-1467 trial.

Other T-cell targets have been also tested. For example, findings on an MS-specific vaccine which attempts at targeting the voltage-gated potassium channel (Kv1.3) have been recently published [127]. These channels regulate the cell membrane potential, control the calcium-induced signaling and are highly expressed on activated T-cells, microglia, and macrophages [128]. Furthermore, pharmacological inhibition of Kv1.3 leads to lower pro-inflammatory cytokine production and diminished proliferation of autoantigen-specific T-cells [129]. In response, a prototype vaccine carrying both Kv1.3-specific epitope and promiscuous foreign T-cell PADRE epitope was created and termed PADRE-Kv1.3 [127]. After receiving two booster doses, the vaccinated rats exhibited stable and high levels of anti-Kv1.3 antibodies levels, with no side effects being observed [127]. When compared to placebo experimental autoimmune encephalomyelitis (EAE) groups, vaccinated EAE rats showed a significantly prolonged disease onset, lower initial disability peak and overall clinical disability scores [127]. The clinical features were accompanied by a lower frequency of pro-inflammatory T-cells (IFN- $\gamma$-producing and Th17), an increase in anti-inflammatory IL-10-secreting T-cells, lower T-cell infiltration, and a greater microglia shift towards an M2 subtype [127]. Experimental vaccination studies also attempt at upregulating the anti-inflammatory Treg cell populations [130]. A vaccine containing pVAX vector, which contained a Mycobacterium leprae-derived gene that encoded heat-shock protein 65 (hsp65), was produced [130]. After four doses of the pVAXhsp65 vaccine, the vaccinated EAE mice demonstrated higher levels of IFN- $\gamma$ and anti-inflammatory IL-10 cytokines [130]. Despite the cytokine alterations and some clinical improvement, no peripheral nor CNS changes in the frequency of autoimmune $\mathrm{CD}^{+} / \mathrm{CD} 25^{+} /$Foxp3 $^{+}$T-cells were noted [130].

An alternative vaccination strategy includes injection of DNA plasmids that contain selected antigens. The balance between an inflammatory immune response and induction of tolerance can be therefore controlled by the route, dose, and the modifications of the injected DNA-encoded antigen [131]. In the case of MS, DNA-based vaccines aimed to induce a greater rate of tolerance towards the myelin-based antigens and produce a shift towards a Th2 response [131,132].

Two MS DNA vaccine trials (both by Bayhill Therapeutics) have been conducted $[133,134]$. The first placebo-controlled study utilized a DNA vaccine containing full-length of the human MBP named BHT-3009 and recruited 30 RRMS or SPMS patients which were allocated to placebo, BHT-3009 alone, or BHT-3009 and atorvastatin [133]. No severe adverse events were reported and the study reported a non-significant trend of lower MRI-detected lesion activity [133]. Flow cytometric analysis showed that 5 out of 6 patients treated with the BHT-3009 showed a significant decline in IFN- $\gamma$-producing CD4+ T-cells, with the response lasting up to 50 weeks after initiation [133]. Furthermore, three patients underwent lumbar puncture both at baseline and follow-up visits and showed a decrease in CSF-derived autoantibodies towards not only MBP, but also towards PLP, MOG, and $\alpha \mathrm{B}$-crysallin [133]. 
This phase I/II trial demonstrated that DNA vaccination with myelin antigen did not produce immune activation, but rather produced tolerance towards multiple epitopes, a phenomenon called "bystander suppression". A second larger phase II trial utilizing the same DNA vaccine was also conducted [134]. A final sample of 267 RRMS patients were randomized to placebo, $0.5 \mathrm{mg}$, or $1.5 \mathrm{mg}$ monthly dose of BHT-3009 and were followed for 44 weeks [134]. The intervention did not result in any differences in terms of time to first relapse, annualized rate of relapses, and disability progression [134]. The lower dose of $0.5 \mathrm{mg}$ BHT-3009 did have favorable but non-significant MRI outcomes, whereas the higher $1.5 \mathrm{mg}$ dose did not have any effect [134]. During the $28-48$ week period, the $0.5 \mathrm{mg}$ BHT-3009 group had a trending 50\% reduction in new enhancing lesions and at week 48 had a significant decrease in a mean volume of enhancing lesions when compared to the placebo [134]. The subgroup with CSF analysis showed that $0.5 \mathrm{mg}$ of BHT-3009 produced a significant decrease in reactivity towards 23 different myelin autoantigens. In contrast, the $1.5 \mathrm{mg}$ BHT-3009 group showed an increase in titers towards the examined PLP epitopes [134]. The authors have outlined the deleterious effect of the higher DNA vaccine dose to a greater percentage of immunostimulatory $\mathrm{CpG}$ motifs present in the DNA plasmid of the vaccine [134]. Due to funding restrictions, future investigation into this type of DNA vaccine remains uncertain. A recent joint effort between Genentech and Bayhill Therapeutics in development of similar type I diabetes vaccine may potentially revitalize the DNA vaccine MS program.

Lastly, MS-based vaccines targeting the B-cell pathway have been constructed. B-cell-activating factor (BAFF), alternatively called a B-lymphocyte stimulator (BLyS), is a potent modulator of B-cell differentiation and has been previously targeted in MS patients $[135,136]$. Therefore, by merging BLyS with tetanus toxoid T-cell epitope, the immune system will elicit an autoimmune response which will inhibit the in-vivo activity of BLyS [137]. BLyS-treated EAE mice created stable and high level of antibodies that caused a decline in B-cell proliferation and a decrease in clinical scores when compared to the control mice group [137]. Given that BAFF manipulation has historically resulted in negative MS disease outcomes, there is a need for better understanding the B-cell pathway before deploying such vaccines. A summary of the MS-based targets and the current stage of vaccine development is highlighted in Table 2.

Table 2. Vaccine development for multiple sclerosis treatment.

\begin{tabular}{|c|c|c|c|c|}
\hline Vaccine & Name & Mechanism of Action & $\begin{array}{l}\text { Latest Stage of } \\
\text { Development }\end{array}$ & Clinical Trial Results \\
\hline $\begin{array}{c}\text { T-cell } \\
\text { vaccine }\end{array}$ & $\begin{array}{l}\text { Imilecleucel-T } \\
\text { (Tcelna } 囚)\end{array}$ & $\begin{array}{l}\text { Inducing immune } \\
\text { response towards } \\
\text { MS-specific T-cells }\end{array}$ & $\begin{array}{c}\text { Phase II ( } n=183 \text { SPMS) } \\
\text { and Phase II ( } n=150 \\
\text { RRMS, randomized to } \\
\text { T-cell vaccine or placebo) }\end{array}$ & $\begin{array}{c}\text { - No effect in overall ITT } \\
\text { group - Non-significant } \\
56 \% \text { - Significant } \\
\text { reduction in relapses- No } \\
\text { effect in SPMS }\end{array}$ \\
\hline $\begin{array}{c}\text { TCR } \\
\text { vaccine }\end{array}$ & $\begin{array}{c}\text { TCR-CDR2 } \\
\text { peptide vaccine } \\
\text { (NeuroVaxß) }\end{array}$ & $\begin{array}{l}\text { Targeting MS-specific } \\
\text { T-cell receptor sequences }\end{array}$ & $\begin{array}{l}\text { Phase I/II ( } n=37 \mathrm{MS}, \\
\text { randomized to } \\
\text { vaccine or placebo) }\end{array}$ & $\begin{array}{l}\text { - No clinical nor } \\
\text { radiological effect }\end{array}$ \\
\hline \multirow[t]{2}{*}{$\begin{array}{l}\text { Peptide } \\
\text { vaccine }\end{array}$} & $\begin{array}{c}\text { MBP85-99, } \\
\text { PLP139-151 } \\
\text { and MOG35-55 } \\
\text { mixture }\end{array}$ & $\begin{array}{c}\text { Inducing tolerance } \\
\text { towards MBP, LPL } \\
\text { and MOG }\end{array}$ & $\begin{array}{c}\text { Phase IIa ( } n=30 \text { RRMS, } \\
\text { randomized to placebo, } \\
1 \mathrm{mg} \text { and } 10 \mathrm{mg} \\
\text { mixture of antigens) }\end{array}$ & $\begin{array}{c}\text { - Statistically significant } \\
66.5 \% \text { reduction in } \\
\text { Gd-enhancing lesions } \\
\text { compared to placebo }\end{array}$ \\
\hline & ATX-MS-1467 & Inducing MBP tolerance & $\begin{array}{l}\text { Phase IIa ( } n=37 \text { RRMS, } \\
\text { all on ATX-MS-1467) }\end{array}$ & $\begin{array}{l}\text { - Statistically significant } \\
46 \% \text { reduction in Gd- } \\
\text { enhancing lesions } \\
\text { compared } \\
\text { to pre-treatment period }\end{array}$ \\
\hline $\begin{array}{c}\text { DNA } \\
\text { vaccine }\end{array}$ & BHT-3009 & Inducing MBP tolerance & $\begin{array}{l}\text { Phase IIb }(n=257 \\
\text { RRMS, randomized to } \\
\text { placebo, } 0.5 \mathrm{mg} \text { and } \\
1.5 \mathrm{mg} \text { BHT-3009) }\end{array}$ & $\begin{array}{l}\text { - Non-significant } \\
50 \% \text { reduction in } \\
\text { Gd-enhancing lesions } \\
\text { compared to placebo }\end{array}$ \\
\hline
\end{tabular}


Table 2. Cont.

\begin{tabular}{|c|c|c|c|c|}
\hline Vaccine & Name & Mechanism of Action & $\begin{array}{l}\text { Latest Stage of } \\
\text { Development }\end{array}$ & Clinical Trial Results \\
\hline $\begin{array}{c}\text { B-cell } \\
\text { pathway }\end{array}$ & TT-BLyS & $\begin{array}{c}\text { Inhibit B-cell } \\
\text { proliferation } \\
\text { through blocking B-cell } \\
\text { activating factor }\end{array}$ & Pre-clinical & - \\
\hline \multirow[t]{2}{*}{$\begin{array}{l}\text { Other } \\
\text { targets }\end{array}$} & PADRE-Kv1.3 & $\begin{array}{c}\text { Inhibit voltage-gated } \\
\text { potassium channel } \\
(\mathrm{Kv} 1.3)\end{array}$ & Pre-clinical & - \\
\hline & pVAXhsp65 & $\begin{array}{c}\text { Promoting regulatory } \\
\text { T-cell proliferation } \\
\text { through } \\
\text { upregulation of HSP65 }\end{array}$ & Pre-clinical & - \\
\hline
\end{tabular}

MS - multiple sclerosis, RRMS - relapsing-remitting multiple sclerosis, SPMS - secondary-progressive multiple sclerosis, CDR - complementarity-determining region, TCR - T-cell receptor, MBP - myelin basic protein, PLP myelin protolipid protein, MOG - myelin oligodendrocyte glycoprotein, Gd - gadolinium, PADRE - pan HLD DR-binding epitope, Kv1.3 - potassium voltage-gated channel (shaker-related subfamily, member 3), TT-BlyS tetanus toxoid - b-lymphocyte stimulator, HSP65- heat-sensitive protein 65.

\section{Immunization Recommendations for Multiple Sclerosis Patients}

Since the last published AAN practice guidelines regarding immunization in MS dating from 2002, epidemiological changes and emergence of new treatment protocols have drastically changed the overall disease settings [138]. Furthermore, interim reports have suggested that some immunization protocols may contribute to greater MS susceptibility and an increase in MS disease activity. Lastly, the significant immunosuppressive DMT effect may modulate the effectiveness of the vaccines by lowering the capability of the immune system to mount an effective response. In response to these new considerations, a new systematic review performed by the AAN has updated their practice guidelines [139]. Although some aspects were previously mentioned in this review, hereafter we will discuss the rationale and conclusion derived from the updated recommendations.

Eight recommendation statements encompassed aspects ranging from general immunization policies for MS patients, immunization during immunosuppressive and immunomodulatory drug use, and immunization during an active MS relapse. Firstly and most importantly, the AAN expert panel did not find definite evidence which would suggests that immunization can increase the risk for developing MS. Furthermore, they concluded that HPV, tetanus toxoid, pertussis, and smallpox vaccine may actually lower the risk for future MS diagnosis. That being said, vaccination of MS patients will not only contribute towards greater protection from developing infections, but also the MS population will continue to contribute to the herd immunity of the local community. When it comes to BCG vaccination, the AAN panel recommends following the WHO guidelines which vary based on the local prevalence of tuberculosis, children and older adults with negative tuberculin, or IFN- $\gamma$ release assay and/or work-related risks involving health care and research, travel, and prison settings. The forth recommendation statement addressed the yearly influenza vaccination in MS patients on immunosuppressive therapy. As previously mentioned, some studies have suggested that there is an increased risk of MS exacerbation after influenza vaccination. The panel finds insufficient evidence to support or refute such associations. However, the recommendation does outline that patients treated with fingolimod, glatiramer acetate, mitoxantrone, and rituximab have lower responsiveness to the influenza vaccine. The panel agrees and recommends information provision by each individual prescribing these drugs. (Table 3) Infection screening guidelines before the initiation of such DMTs are also shown in Table 3. Apart from the prescribing information, the panel also provides a general encompassing statement which recommends against routine use of live-attenuated vaccines in patients that use or recently discontinued using DMT. Lastly, the guidelines suggest restraining of vaccination with live-attenuated vaccines in patients that are actively experiencing an MS relapse and during the period of three months after receiving high-dose systemic steroids. In line with the described AAN 
recommendations, a similar French-based recommendation has been issued. [140]. In addition to the MS-specific circumstances, the French providers responsible for the treatment and care of MS patients are recommended to follow the vaccination standards of the French High Council of Healthy which incorporates specific sections for immunocompromised populations [140].

Table 3. Screening and live-vaccination before, during, and after immunosuppressive treatment of MS patients.

\begin{tabular}{|c|c|c|c|c|}
\hline $\begin{array}{l}\text { Prescribing } \\
\text { Information }\end{array}$ & Screening & $\begin{array}{l}\text { Vaccination } \\
\text { before DMT }\end{array}$ & $\begin{array}{c}\text { Vaccination } \\
\text { during DMT Use }\end{array}$ & $\begin{array}{l}\text { Vaccination after } \\
\text { Discontinuation }\end{array}$ \\
\hline Fingolimod & Active TB and Hepatitis B & 1 month & Avoid live-vaccines & 2 months \\
\hline Teriflunomide & TB & - & Avoid live-vaccines & 6 months \\
\hline Alemtuzumab & $\mathrm{TB}^{+}$, varicella, $\mathrm{VZV}$ & 6 weeks & Avoid live-vaccines & "recent" treatment \\
\hline Ocrelizumab & Active Hepatitis B & 4 weeks* & Avoid live-vaccines & until repletion \\
\hline
\end{tabular}

Such recommendations provided by the major professional associations can contribute to more uniform vaccine use in settings of a chronic disease such as MS. The majority of the MS-based recommendations are similar in context when compared to other diseases like the autoimmune inflammatory rheumatic diseases (AIIRD). The European League against Rheumatism (EULAR) has issued comparable recommendations statements, including an inclusion of regular influenza vaccination, avoidance of live-attenuated vaccines, vaccination before the initiation of B-cell depleting therapy, and during stable disease periods. [141]. However, criteria formation through the use of only case-controlled studies as part of the meta-analysis process does have some limitations. The use of large international registries may help in identifying special circumstances and specific populations that exhibit alternative risk to benefit ratios.

\section{Conclusions}

Standard immunization protocols are not contributing towards greater MS risk and higher disease activity. In contrast to the aforementioned concerns, immunization strategies targeting certain pathogens may potentially provide additional clinical benefits that are pertinent to the overall health of the MS population. Despite the lower vaccination response rate, MS patients should be active participants in maintaining the overall herd immunity towards common vaccine-preventable diseases. Multiple vaccine/gene-based therapies continue to be developed and investigated in clinical trials; however, results to date have failed to achieve desired clinical outcomes. Treatment prospects including antigen desensitization and DNA vaccination are currently re-emerging as potentially viable new methods of targeting the complex MS pathophysiology. Before investing in costly research and development of new vaccine-based therapies, additional efforts targeting our emerging knowledge on disease mechanisms remains a priority.

Author Contributions: Data curation D.J.; writing—original draft preparation D.J.; writing—review and editing D.J., B.W.-G., M.R., M.G.D. and R.Z.; All authors have read and agreed to the published version of the manuscript.

Funding: This research received no external funding.

Conflicts of Interest: D.J. has nothing to declare. B.W-G. received honoraria as a speaker and as a consultant for Biogen Idec, Teva Pharmaceuticals, EMD Serono, Novartis, Genentech and Mallickrodt. B.W-G. received research funds from Biogen Idec, Teva Pharmaceuticals, EMD Serono, Novartis, Genentech and Mallinckrodt. M.R. received research funding or consulting fees from the National Multiple Sclerosis Society, the Department of Defense, the National Institutes of Health, National Science Foundation and Otuska Pharmaceutical Development. M.G.D. has received research grant support from Novartis and Keystone Heart. R.Z. received personal compensation from EMD Serono, Genzyme-Sanofi, Celgene and Novartis for speaking and consultant fees. He received financial 
support for research activities from Genzyme-Sanofi, Novartis, Celgene, Mapi Pharma, Keystone Heart and Protembis. None of the disclosures are related to this manuscript.

\section{References}

1. Jakimovski, D.; Weinstock-Guttman, B.; Hagemeier, J.; Vaughn, C.B.; Kavak, K.S.; Gandhi, S.; Bennett, S.E.; Fuchs, T.A.; Bergsland, N.; Dwyer, M.G.; et al. Walking disability measures in multiple sclerosis patients: Correlations with MRI-derived global and microstructural damage. J. Neurol. Sci. 2018, 393, 128-134. [CrossRef] [PubMed]

2. Jakimovski, D.; Guan, Y.; Ramanathan, M.; Weinstock-Guttman, B.; Zivadinov, R. Lifestyle-based modifiable risk factors in multiple sclerosis: Review of experimental and clinical findings. Neurodegener. Dis. Manag. 2019, 9, 149-172. [CrossRef] [PubMed]

3. Leibowitz, U.; Antonovsky, A.; Medalie, J.M.; Smith, H.A.; Halpern, L.; Alter, M. Epidemiological study of multiple sclerosis in Israel. II. Multiple sclerosis and level of sanitation. J. Neurol. Neurosurg. Psychiatry 1966, 29, 60-68. [CrossRef] [PubMed]

4. Bach, J.F. The effect of infections on susceptibility to autoimmune and allergic diseases. N. Engl. J. Med. 2002, 347, 911-920. [CrossRef]

5. Fleming, J.O.; Cook, T.D. Multiple sclerosis and the hygiene hypothesis. Neurology 2006, 67, $2085-2086$. [CrossRef]

6. Ponsonby, A.L.; Van der Mei, I.; Dwyer, T.; Blizzard, L.; Taylor, B.; Kemp, A.; Simmons, R.; Kilpatrick, T. Exposure to infant siblings during early life and risk of multiple sclerosis. JAMA 2005, 293, 463-469. [CrossRef]

7. Norgaard, M.; Nielsen, R.B.; Jacobsen, J.B.; Gradus, J.L.; Stenager, E.; Koch-Henriksen, N.; Lash, T.L.; Sorensen, H.T. Use of penicillin and other antibiotics and risk of multiple sclerosis: A population-based case-control study. Am. J. Epidemiol. 2011, 174, 945-948. [CrossRef]

8. Jakimovski, D.; Kolb, C.; Ramanathan, M.; Zivadinov, R.; Weinstock-Guttman, B. Interferon beta for Multiple Sclerosis. Cold Spring Harb. Perspect. Med. 2018, 8. [CrossRef]

9. Gandhi, S.; Jakimovski, D.; Ahmed, R.; Hojnacki, D.; Kolb, C.; Weinstock-Guttman, B.; Zivadinov, R. Use of natalizumab in multiple sclerosis: Current perspectives. Expert Opin. Biol. Ther. 2016, 16, 1151-1162. [CrossRef]

10. Rae-Grant, A.; Day, G.S.; Marrie, R.A.; Rabinstein, A.; Cree, B.A.C.; Gronseth, G.S.; Haboubi, M.; Halper, J.; Hosey, J.P.; Jones, D.E.; et al. Practice guideline recommendations summary: Disease-modifying therapies for adults with multiple sclerosis: Report of the Guideline Development, Dissemination, and Implementation Subcommittee of the American Academy of Neurology. Neurology 2018, 90, 777-788. [CrossRef]

11. Gravina, A.G.; Zagari, R.M.; De Musis, C.; Romano, L.; Loguercio, C.; Romano, M. Helicobacter pylori and extragastric diseases: A review. World J. Gastroenterol. 2018, 24, 3204-3221. [CrossRef] [PubMed]

12. Gasbarrini, A.; Franceschi, F.; Tartaglione, R.; Landolfi, R.; Pola, P.; Gasbarrini, G. Regression of autoimmune thrombocytopenia after eradication of Helicobacter pylori. Lancet 1998, 352, 878. [CrossRef]

13. Li, W.; Minohara, M.; Piao, H.; Matsushita, T.; Masaki, K.; Matsuoka, T.; Isobe, N.; Su, J.J.; Ohyagi, Y.; Kira, J. Association of anti-Helicobacter pylori neutrophil-activating protein antibody response with anti-aquaporin-4 autoimmunity in Japanese patients with multiple sclerosis and neuromyelitis optica. Mult. Scler. 2009, 15, 1411-1421. [CrossRef] [PubMed]

14. Pedrini, M.J.; Seewann, A.; Bennett, K.A.; Wood, A.J.; James, I.; Burton, J.; Marshall, B.J.; Carroll, W.M.; Kermode, A.G. Helicobacter pylori infection as a protective factor against multiple sclerosis risk in females. J. Neurol. Neurosurg. Psychiatry 2015, 86, 603-607. [CrossRef] [PubMed]

15. Jaruvongvanich, V.; Sanguankeo, A.; Jaruvongvanich, S.; Upala, S. Association between Helicobacter pylori infection and multiple sclerosis: A systematic review and meta-analysis. Mult. Scler. Relat. Disord. 2016, 7 , 92-97. [CrossRef]

16. Yao, G.; Wang, P.; Luo, X.D.; Yu, T.M.; Harris, R.A.; Zhang, X.M. Meta-analysis of association between Helicobacter pylori infection and multiple sclerosis. Neurosci. Lett. 2016, 620, 1-7. [CrossRef]

17. Cook, K.W.; Crooks, J.; Hussain, K.; O’Brien, K.; Braitch, M.; Kareem, H.; Constantinescu, C.S.; Robinson, K.; Gran, B. Helicobacter pylori infection reduces disease severity in an experimental model of multiple sclerosis. Front. Microbiol. 2015, 6, 52. [CrossRef] 
18. Ivanov, I.I.; Atarashi, K.; Manel, N.; Brodie, E.L.; Shima, T.; Karaoz, U.; Wei, D.; Goldfarb, K.C.; Santee, C.A.; Lynch, S.V.; et al. Induction of intestinal Th17 cells by segmented filamentous bacteria. Cell 2009, 139, 485-498. [CrossRef]

19. Oertli, M.; Sundquist, M.; Hitzler, I.; Engler, D.B.; Arnold, I.C.; Reuter, S.; Maxeiner, J.; Hansson, M.; Taube, C.; Quiding-Jarbrink, M.; et al. DC-derived IL-18 drives Treg differentiation, murine Helicobacter pylori-specific immune tolerance, and asthma protection. J. Clin. Invest. 2012, 122, 1082-1096. [CrossRef]

20. Sriram, S.; Stratton, C.W.; Yao, S.; Tharp, A.; Ding, L.; Bannan, J.D.; Mitchell, W.M. Chlamydia pneumoniae infection of the central nervous system in multiple sclerosis. Ann. Neurol. 1999, 46, 6-14. [CrossRef]

21. Munger, K.L.; DeLorenze, G.N.; Levin, L.I.; Rubertone, M.V.; Vogelman, J.H.; Peck, C.A.; Peeling, R.W.; Orentreich, N.; Ascherio, A. A prospective study of Chlamydia pneumoniae infection and risk of MS in two US cohorts. Neurology 2004, 62, 1799-1803. [CrossRef]

22. Gieffers, J.; Pohl, D.; Treib, J.; Dittmann, R.; Stephan, C.; Klotz, K.; Hanefeld, F.; Solbach, W.; Haass, A.; Maass, M. Presence of Chlamydia pneumoniae DNA in the cerebral spinal fluid is a common phenomenon in a variety of neurological diseases and not restricted to multiple sclerosis. Ann. Neurol. 2001, 49, 585-589. [CrossRef] [PubMed]

23. Phe, V.; Pakzad, M.; Curtis, C.; Porter, B.; Haslam, C.; Chataway, J.; Panicker, J.N. Urinary tract infections in multiple sclerosis. Mult. Scler. 2016, 22, 855-861. [CrossRef] [PubMed]

24. Alonso, A.; Jick, S.S.; Jick, H.; Hernan, M.A. Antibiotic use and risk of multiple sclerosis. Am. J. Epidemiol. 2006, 163, 997-1002. [CrossRef] [PubMed]

25. Abdollahpour, I.; Nedjat, S.; Mansournia, M.A.; Eckert, S.; Weinstock-Guttman, B. Infectious exposure, antibiotic use, and multiple sclerosis: A population-based incident case-control study. Acta Neurol. Scand. 2018. [CrossRef]

26. Guan, Y.; Jakimovski, D.; Ramanathan, M.; Weinstock-Guttman, B.; Zivadinov, R. The role of Epstein-Barr virus in multiple sclerosis: From molecular pathophysiology to in vivo imaging. Neural. Regen. Res. 2019, 14, 373-386. [CrossRef]

27. Ascherio, A.; Munger, K.L.; Lennette, E.T.; Spiegelman, D.; Hernan, M.A.; Olek, M.J.; Hankinson, S.E.; Hunter, D.J. Epstein-Barr virus antibodies and risk of multiple sclerosis: A prospective study. JAMA 2001, 286, 3083-3088. [CrossRef]

28. Dobson, R.; Kuhle, J.; Middeldorp, J.; Giovannoni, G. Epstein-Barr-negative MS: A true phenomenon? Neurol. Neuroimmunol. Neuroinflamm. 2017, 4, e318. [CrossRef]

29. Levin, L.I.; Munger, K.L.; O’Reilly, E.J.; Falk, K.I.; Ascherio, A. Primary infection with the Epstein-Barr virus and risk of multiple sclerosis. Ann. Neurol. 2010, 67, 824-830. [CrossRef]

30. Banwell, B.; Krupp, L.; Kennedy, J.; Tellier, R.; Tenembaum, S.; Ness, J.; Belman, A.; Boiko, A.; Bykova, O.; Waubant, E.; et al. Clinical features and viral serologies in children with multiple sclerosis: A multinational observational study. Lancet Neurol. 2007, 6, 773-781. [CrossRef]

31. Langer-Gould, A.; Wu, J.; Lucas, R.; Smith, J.; Gonzales, E.; Amezcua, L.; Haraszti, S.; Chen, L.H.; Quach, H.; James, J.A.; et al. Epstein-Barr virus, cytomegalovirus, and multiple sclerosis susceptibility: A multiethnic study. Neurology 2017. [CrossRef] [PubMed]

32. Munger, K.L.; Hongell, K.; Cortese, M.; Aivo, J.; Soilu-Hanninen, M.; Surcel, H.M.; Ascherio, A. Epstein-Barr virus and multiple sclerosis risk in the Finnish Maternity Cohort. Ann. Neurol. 2019. [CrossRef] [PubMed]

33. Wandinger, K.; Jabs, W.; Siekhaus, A.; Bubel, S.; Trillenberg, P.; Wagner, H.; Wessel, K.; Kirchner, H.; Hennig, H. Association between clinical disease activity and Epstein-Barr virus reactivation in MS. Neurology 2000, 55, 178-184. [CrossRef]

34. Zivadinov, R.; Zorzon, M.; Weinstock-Guttman, B.; Serafin, M.; Bosco, A.; Bratina, A.; Maggiore, C.; Grop, A.; Tommasi, M.A.; Srinivasaraghavan, B.; et al. Epstein-Barr virus is associated with grey matter atrophy in multiple sclerosis. J. Neurol. Neurosurg. Psychiatry 2009, 80, 620-625. [CrossRef] [PubMed]

35. Farrell, R.A.; Antony, D.; Wall, G.R.; Clark, D.A.; Fisniku, L.; Swanton, J.; Khaleeli, Z.; Schmierer, K.; Miller, D.H.; Giovannoni, G. Humoral immune response to EBV in multiple sclerosis is associated with disease activity on MRI. Neurology 2009, 73, 32-38. [CrossRef] [PubMed]

36. Zivadinov, R.; Cerza, N.; Hagemeier, J.; Carl, E.; Badgett, D.; Ramasamy, D.P.; Weinstock-Guttman, B.; Ramanathan, M. Humoral response to EBV is associated with cortical atrophy and lesion burden in patients with MS. Neurol. Neuroimmunol. Neuroinflamm. 2016, 3, e190. [CrossRef] 
37. Jakimovski, D.; Ramanathan, M.; Weinstock-Guttman, B.; Bergsland, N.; Ramasamay, D.P.; Carl, E.; Dwyer, M.G.; Zivadinov, R. Higher EBV response is associated with more severe gray matter and lesion pathology in relapsing multiple sclerosis patients: A case-controlled magnetization transfer ratio study. Mult. Scler. 2019. [CrossRef]

38. Morandi, E.; Jagessar, S.A.;'t Hart, B.A.; Gran, B. EBV Infection Empowers Human B Cells for Autoimmunity: Role of Autophagy and Relevance to Multiple Sclerosis. J. Immunol. 2017. [CrossRef]

39. Jagessar, S.A.; Holtman, I.R.; Hofman, S.; Morandi, E.; Heijmans, N.; Laman, J.D.; Gran, B.; Faber, B.W.; van Kasteren, S.I.; Eggen, B.J.; et al. Lymphocryptovirus Infection of Nonhuman Primate B Cells Converts Destructive into Productive Processing of the Pathogenic CD8 T Cell Epitope in Myelin Oligodendrocyte Glycoprotein. J. Immunol. 2016, 197, 1074-1088. [CrossRef]

40. Humme, S.; Reisbach, G.; Feederle, R.; Delecluse, H.J.; Bousset, K.; Hammerschmidt, W.; Schepers, A. The EBV nuclear antigen 1 (EBNA1) enhances B cell immortalization several thousandfold. Proc. Natl. Acad. Sci. USA 2003, 100, 10989-10994. [CrossRef]

41. Dunham, J.; Van Driel, N.; Eggen, B.J.; Paul, C.; t Hart, B.A.; Laman, J.D.; Kap, Y.S. Analysis of the cross-talk of Epstein-Barr virus-infected B cells with T cells in the marmoset. Clin. Transl. Immunol. 2017, 6, e127. [CrossRef]

42. Magliozzi, R.; Serafini, B.; Rosicarelli, B.; Chiappetta, G.; Veroni, C.; Reynolds, R.; Aloisi, F. B-cell enrichment and Epstein-Barr virus infection in inflammatory cortical lesions in secondary progressive multiple sclerosis. J. Neuropathol. Exp. Neurol. 2013, 72, 29-41. [CrossRef]

43. Hassani, A.; Corboy, J.R.; Al-Salam, S.; Khan, G. Epstein-Barr virus is present in the brain of most cases of multiple sclerosis and may engage more than just B cells. PLoS ONE 2018, 13, e0192109. [CrossRef] [PubMed]

44. Moreno, M.A.; Or-Geva, N.; Aftab, B.T.; Khanna, R.; Croze, E.; Steinman, L.; Han, M.H. Molecular signature of Epstein-Barr virus infection in MS brain lesions. Neurol. Neuroimmunol. Neuroinflamm. 2018, 5, e466. [CrossRef] [PubMed]

45. Tengvall, K.; Huang, J.; Hellstrom, C.; Kammer, P.; Bistrom, M.; Ayoglu, B.; Lima Bomfim, I.; Stridh, P.; Butt, J.; Brenner, N.; et al. Molecular mimicry between Anoctamin 2 and Epstein-Barr virus nuclear antigen 1 associates with multiple sclerosis risk. Proc. Natl. Acad. Sci. USA 2019. [CrossRef] [PubMed]

46. Ayoglu, B.; Mitsios, N.; Kockum, I.; Khademi, M.; Zandian, A.; Sjoberg, R.; Forsstrom, B.; Bredenberg, J.; Lima Bomfim, I.; Holmgren, E.; et al. Anoctamin 2 identified as an autoimmune target in multiple sclerosis. Proc. Natl. Acad. Sci. USA 2016, 113, 2188-2193. [CrossRef]

47. Van Zyl, D.G.; Mautner, J.; Delecluse, H.J. Progress in EBV Vaccines. Front. Oncol. 2019, 9, 104. [CrossRef]

48. Boodhoo, N.; Gurung, A.; Sharif, S.; Behboudi, S. Marek's disease in chickens: A review with focus on immunology. Vet. Res. 2016, 47, 119. [CrossRef]

49. Cohen, J.I. Vaccine Development for Epstein-Barr Virus. Adv. Exp. Med. Biol. 2018, 1045, 477-493. [CrossRef]

50. Tang, T.; Weng, T.; Jia, H.; Luo, S.; Xu, Y.; Li, L.; Zhang, P. Harnessing the layer-by-layer assembly technique to design biomaterials vaccines for immune modulation in translational applications. Biomater. Sci. 2019, 7, 715-732. [CrossRef]

51. Cohen, J.I. Epstein-barr virus vaccines. Clin. Transl. Immunol. 2015, 4, e32. [CrossRef] [PubMed]

52. Moutschen, M.; Leonard, P.; Sokal, E.M.; Smets, F.; Haumont, M.; Mazzu, P.; Bollen, A.; Denamur, F.; Peeters, P.; Dubin, G.; et al. Phase I/II studies to evaluate safety and immunogenicity of a recombinant gp350 Epstein-Barr virus vaccine in healthy adults. Vaccine 2007, 25, 4697-4705. [CrossRef] [PubMed]

53. Sokal, E.M.; Hoppenbrouwers, K.; Vandermeulen, C.; Moutschen, M.; Leonard, P.; Moreels, A.; Haumont, M.; Bollen, A.; Smets, F.; Denis, M. Recombinant gp350 vaccine for infectious mononucleosis: A phase 2, randomized, double-blind, placebo-controlled trial to evaluate the safety, immunogenicity, and efficacy of an Epstein-Barr virus vaccine in healthy young adults. J. Infect. Dis. 2007, 196, 1749-1753. [CrossRef] [PubMed]

54. Xia, Z.; White, C.C.; Owen, E.K.; Von Korff, A.; Clarkson, S.R.; McCabe, C.A.; Cimpean, M.; Winn, P.A.; Hoesing, A.; Steele, S.U.; et al. Genes and Environment in Multiple Sclerosis project: A platform to investigate multiple sclerosis risk. Ann. Neurol. 2016, 79, 178-189. [CrossRef]

55. Pudney, V.A.; Leese, A.M.; Rickinson, A.B.; Hislop, A.D. CD8+ immunodominance among Epstein-Barr virus lytic cycle antigens directly reflects the efficiency of antigen presentation in lytically infected cells. J. Exp. Med. 2005, 201, 349-360. [CrossRef] 
56. Brooks, J.M.; Long, H.M.; Tierney, R.J.; Shannon-Lowe, C.; Leese, A.M.; Fitzpatrick, M.; Taylor, G.S.; Rickinson, A.B. Early T Cell Recognition of B Cells following Epstein-Barr Virus Infection: Identifying Potential Targets for Prophylactic Vaccination. PLoS Pathog. 2016, 12, e1005549. [CrossRef]

57. Hartlage, A.S.; Liu, T.; Patton, J.T.; Garman, S.L.; Zhang, X.; Kurt, H.; Lozanski, G.; Lustberg, M.E.; Caligiuri, M.A.; Baiocchi, R.A. The Epstein-Barr Virus Lytic Protein BZLF1 as a Candidate Target Antigen for Vaccine Development. Cancer Immunol. Res. 2015, 3, 787-794. [CrossRef]

58. Jakimovski, D.; Weinstock-Guttman, B.; Ramanathan, M.; Kolb, C.; Hojnacki, D.; Minagar, A.; Zivadinov, R. Ocrelizumab: A B-cell depleting therapy for multiple sclerosis. Expert Opin. Biol. Ther. 2017, 17, 1163-1172. [CrossRef]

59. Pender, M.P.; Csurhes, P.A.; Burrows, J.M.; Burrows, S.R. Defective T-cell control of Epstein-Barr virus infection in multiple sclerosis. Clin. Transl. Immunol. 2017, 6, e126. [CrossRef]

60. Antsiferova, O.; Muller, A.; Ramer, P.C.; Chijioke, O.; Chatterjee, B.; Raykova, A.; Planas, R.; Sospedra, M.; Shumilov, A.; Tsai, M.H.; et al. Adoptive transfer of EBV specific CD8+ T cell clones can transiently control EBV infection in humanized mice. PLoS Pathog. 2014, 10, e1004333. [CrossRef] [PubMed]

61. Angelini, D.F.; Serafini, B.; Piras, E.; Severa, M.; Coccia, E.M.; Rosicarelli, B.; Ruggieri, S.; Gasperini, C.; Buttari, F.; Centonze, D.; et al. Increased CD8+ T cell response to Epstein-Barr virus lytic antigens in the active phase of multiple sclerosis. PLoS Pathog. 2013, 9, e1003220. [CrossRef] [PubMed]

62. Serafini, B.; Rosicarelli, B.; Veroni, C.; Mazzola, G.A.; Aloisi, F. Epstein-Barr virus-specific CD8 T cells selectively infiltrate the multiple sclerosis brain and interact locally with virus infected cells: Clue for a virus-driven immunopathological mechanism. J. Virol. 2019. [CrossRef] [PubMed]

63. Melenhorst, J.J.; Leen, A.M.; Bollard, C.M.; Quigley, M.F.; Price, D.A.; Rooney, C.M.; Brenner, M.K.; Barrett, A.J.; Heslop, H.E. Allogeneic virus-specific T cells with HLA alloreactivity do not produce GVHD in human subjects. Blood 2010, 116, 4700-4702. [CrossRef] [PubMed]

64. Pender, M.P.; Csurhes, P.A.; Smith, C.; Douglas, N.L.; Neller, M.A.; Matthews, K.K.; Beagley, L.; Rehan, S.; Crooks, P.; Hopkins, T.J.; et al. Epstein-Barr virus-specific T cell therapy for progressive multiple sclerosis. JCI Insight 2018, 3. [CrossRef] [PubMed]

65. Mameli, G.; Poddighe, L.; Mei, A.; Uleri, E.; Sotgiu, S.; Serra, C.; Manetti, R.; Dolei, A. Expression and activation by Epstein Barr virus of human endogenous retroviruses-W in blood cells and astrocytes: Inference for multiple sclerosis. PLoS One 2012, 7, e44991. [CrossRef] [PubMed]

66. Kury, P.; Nath, A.; Creange, A.; Dolei, A.; Marche, P.; Gold, J.; Giovannoni, G.; Hartung, H.P.; Perron, H. Human Endogenous Retroviruses in Neurological Diseases. Trends Mol. Med. 2018. [CrossRef] [PubMed]

67. Gifford, R.; Tristem, M. The evolution, distribution and diversity of endogenous retroviruses. Virus Genes 2003, 26, 291-315. [CrossRef] [PubMed]

68. Morandi, E.; Tanasescu, R.; Tarlinton, R.E.; Constantinescu, C.S.; Zhang, W.; Tench, C.; Gran, B. The association between human endogenous retroviruses and multiple sclerosis: A systematic review and meta-analysis. PLoS ONE 2017, 12, e0172415. [CrossRef] [PubMed]

69. Perron, H.; Germi, R.; Bernard, C.; Garcia-Montojo, M.; Deluen, C.; Farinelli, L.; Faucard, R.; Veas, F.; Stefas, I.; Fabriek, B.O.; et al. Human endogenous retrovirus type $\mathrm{W}$ envelope expression in blood and brain cells provides new insights into multiple sclerosis disease. Mult. Scler. 2012, 18, 1721-1736. [CrossRef]

70. Curtin, F.; Perron, H.; Kromminga, A.; Porchet, H.; Lang, A.B. Preclinical and early clinical development of GNbAC1, a humanized IgG4 monoclonal antibody targeting endogenous retroviral MSRV-Env protein. MAbs 2015, 7, 265-275. [CrossRef]

71. Madeira, A.; Burgelin, I.; Perron, H.; Curtin, F.; Lang, A.B.; Faucard, R. MSRV envelope protein is a potent, endogenous and pathogenic agonist of human toll-like receptor 4: Relevance of GNbAC1 in multiple sclerosis treatment. J. Neuroimmunol. 2016, 291, 29-38. [CrossRef]

72. Derfuss, T.; Curtin, F.; Guebelin, C.; Bridel, C.; Rasenack, M.; Matthey, A.; Du Pasquier, R.; Schluep, M.; Desmeules, J.; Lang, A.B.; et al. A phase IIa randomised clinical study of GNbAC1, a humanised monoclonal antibody against the envelope protein of multiple sclerosis-associated endogenous retrovirus in multiple sclerosis patients. Mult. Scler. 2015, 21, 885-893. [CrossRef] [PubMed]

73. Kremer, D.; Schichel, T.; Forster, M.; Tzekova, N.; Bernard, C.; Van der Valk, P.; Van Horssen, J.; Hartung, H.P.; Perron, H.; Kury, P. Human endogenous retrovirus type $\mathrm{W}$ envelope protein inhibits oligodendroglial precursor cell differentiation. Ann. Neurol. 2013, 74, 721-732. [CrossRef] [PubMed] 
74. Black, S.; Eskola, J.; Siegrist, C.A.; Halsey, N.; MacDonald, N.; Law, B.; Miller, E.; Andrews, N.; Stowe, J.; Salmon, D.; et al. Importance of background rates of disease in assessment of vaccine safety during mass immunisation with pandemic H1N1 influenza vaccines. Lancet 2009, 374, 2115-2122. [CrossRef]

75. Marshall, E. A shadow falls on hepatitis B vaccination effort. Science 1998, 281, 630-631. [CrossRef]

76. Ascherio, A.; Zhang, S.M.; Hernan, M.A.; Olek, M.J.; Coplan, P.M.; Brodovicz, K.; Walker, A.M. Hepatitis B vaccination and the risk of multiple sclerosis. N. Engl. J. Med. 2001, 344, 327-332. [CrossRef]

77. Sadovnick, A.D.; Scheifele, D.W. School-based hepatitis B vaccination programme and adolescent multiple sclerosis. Lancet 2000, 355, 549-550. [CrossRef]

78. Mikaeloff, Y.; Caridade, G.; Suissa, S.; Tardieu, M. Hepatitis B vaccine and the risk of CNS inflammatory demyelination in childhood. Neurology 2009, 72, 873-880. [CrossRef]

79. Mikaeloff, Y.; Caridade, G.; Assi, S.; Tardieu, M.; Suissa, S.; KIDSEP study group of the French Neuropaediatric Society. Hepatitis B vaccine and risk of relapse after a first childhood episode of CNS inflammatory demyelination. Brain 2007, 130, 1105-1110. [CrossRef]

80. Confavreux, C.; Suissa, S.; Saddier, P.; Bourdes, V.; Vukusic, S.; Vaccines in Multiple Sclerosis Study, G. Vaccinations and the risk of relapse in multiple sclerosis. Vaccines in Multiple Sclerosis Study Group. N. Engl. J. Med. 2001, 344, 319-326. [CrossRef]

81. Sestili, C.; Grazina, I.; La Torre, G. HBV vaccine and risk of developing multiple sclerosis: A systematic review and meta-analysis. Hum. Vaccin. Immunother. 2018. [CrossRef] [PubMed]

82. $\quad$ Langer-Gould, A.; Qian, L.; Tartof, S.Y.; Brara, S.M.; Jacobsen, S.J.; Beaber, B.E.; Sy, L.S.; Chao, C.; Hechter, R.; Tseng, H.F. Vaccines and the risk of multiple sclerosis and other central nervous system demyelinating diseases. JAMA Neurol. 2014, 71, 1506-1513. [CrossRef] [PubMed]

83. Scheller, N.M.; Svanstrom, H.; Pasternak, B.; Arnheim-Dahlstrom, L.; Sundstrom, K.; Fink, K.; Hviid, A. Quadrivalent HPV vaccination and risk of multiple sclerosis and other demyelinating diseases of the central nervous system. JAMA 2015, 313, 54-61. [CrossRef] [PubMed]

84. Sridhar, G.; Tian, F.; Forshee, R.; Kulldorff, M.; Selvam, N.; Sutherland, A.; Bryan, W.; Barone, S.; Xu, L.; Izurieta, H.S. Evaluation of optic neuritis following human papillomavirus vaccination. Hum. Vaccin. Immunother. 2017, 13, 1705-1713. [CrossRef]

85. Mouchet, J.; Salvo, F.; Raschi, E.; Poluzzi, E.; Antonazzo, I.C.; De Ponti, F.; Begaud, B. Human papillomavirus vaccine and demyelinating diseases-A systematic review and meta-analysis. Pharmacol. Res. 2018, 132, 108-118. [CrossRef]

86. Massa, J.; Munger, K.L.; O’Reilly, E.J.; Levin, L.I.; Ascherio, A. Serum titers of IgG antibodies against tetanus and diphtheria toxoids and risk of multiple sclerosis. J. Neuroimmunol. 2009, 208, 141-142. [CrossRef]

87. DeStefano, F.; Verstraeten, T.; Jackson, L.A.; Okoro, C.A.; Benson, P.; Black, S.B.; Shinefield, H.R.; Mullooly, J.P.; Likosky, W.; Chen, R.T.; et al. Vaccinations and risk of central nervous system demyelinating diseases in adults. Arch. Neurol. 2003, 60, 504-509. [CrossRef]

88. Hernan, M.A.; Alonso, A.; Hernandez-Diaz, S. Tetanus vaccination and risk of multiple sclerosis: A systematic review. Neurology 2006, 67, 212-215. [CrossRef]

89. McNicholas, N.; Chataway, J. Relapse risk in patients with multiple sclerosis after H1N1 vaccination, with or without seasonal influenza vaccination. J. Neurol. 2011, 258, 1545-1547. [CrossRef]

90. Farez, M.F.; Ysrraelit, M.C.; Fiol, M.; Correale, J. H1N1 vaccination does not increase risk of relapse in multiple sclerosis: A self-controlled case-series study. Mult. Scler. 2012, 18, 254-256. [CrossRef]

91. Miller, A.E.; Morgante, L.A.; Buchwald, L.Y.; Nutile, S.M.; Coyle, P.K.; Krupp, L.B.; Doscher, C.A.; Lublin, F.D.; Knobler, R.L.; Trantas, F.; et al. A multicenter, randomized, double-blind, placebo-controlled trial of influenza immunization in multiple sclerosis. Neurology 1997, 48, 312-314. [CrossRef] [PubMed]

92. Blackmore, S.; Hernandez, J.; Juda, M.; Ryder, E.; Freund, G.G.; Johnson, R.W.; Steelman, A.J. Influenza infection triggers disease in a genetic model of experimental autoimmune encephalomyelitis. Proc. Natl. Acad. Sci. USA 2017, 114, E6107-E6116. [CrossRef] [PubMed]

93. Ristori, G.; Buzzi, M.G.; Sabatini, U.; Giugni, E.; Bastianello, S.; Viselli, F.; Buttinelli, C.; Ruggieri, S.; Colonnese, C.; Pozzilli, C.; et al. Use of Bacille Calmette-Guerin (BCG) in multiple sclerosis. Neurology 1999, 53, 1588-1589. [CrossRef]

94. Ristori, G.; Romano, S.; Cannoni, S.; Visconti, A.; Tinelli, E.; Mendozzi, L.; Cecconi, P.; Lanzillo, R.; Quarantelli, M.; Buttinelli, C.; et al. Effects of Bacille Calmette-Guerin after the first demyelinating event in the CNS. Neurology 2014, 82, 41-48. [CrossRef] 
95. Cossu, D.; Yokoyama, K.; Tomizawa, Y.; Momotani, E.; Hattori, N. Altered humoral immunity to mycobacterial antigens in Japanese patients affected by inflammatory demyelinating diseases of the central nervous system. Sci. Rep. 2017, 7, 3179. [CrossRef] [PubMed]

96. Biet, F.; Bay, S.; Thibault, V.C.; Euphrasie, D.; Grayon, M.; Ganneau, C.; Lanotte, P.; Daffe, M.; Gokhale, R.; Etienne, G.; et al. Lipopentapeptide induces a strong host humoral response and distinguishes Mycobacterium avium subsp. paratuberculosis from M. avium subsp. avium. Vaccine 2008, 26, 257-268. [CrossRef]

97. Cossu, D.; Yokoyama, K.; Sakanishi, T.; Momotani, E.; Hattori, N. Adjuvant and antigenic properties of Mycobacterium avium subsp. paratuberculosis on experimental autoimmune encephalomyelitis. J. Neuroimmunol. 2019, 330, 174-177. [CrossRef]

98. Moriabadi, N.F.; Niewiesk, S.; Kruse, N.; Jung, S.; Weissbrich, B.; ter Meulen, V.; Toyka, K.V.; Rieckmann, P. Influenza vaccination in MS: Absence of T-cell response against white matter proteins. Neurology 2001, 56, 938-943. [CrossRef]

99. Schwid, S.R.; Decker, M.D.; Lopez-Bresnahan, M.; Rebif-Influenza Vaccine Study, I. Immune response to influenza vaccine is maintained in patients with multiple sclerosis receiving interferon beta-1a. Neurology 2005, 65, 1964-1966. [CrossRef]

100. Mehling, M.; Fritz, S.; Hafner, P.; Eichin, D.; Yonekawa, T.; Klimkait, T.; Lindberg, R.L.; Kappos, L.; Hess, C. Preserved antigen-specific immune response in patients with multiple sclerosis responding to IFNbeta-therapy. PLoS ONE 2013, 8, e78532. [CrossRef]

101. Bar-Or, A.; Freedman, M.S.; Kremenchutzky, M.; Menguy-Vacheron, F.; Bauer, D.; Jodl, S.; Truffinet, P.; Benamor, M.; Chambers, S.; O'Connor, P.W. Teriflunomide effect on immune response to influenza vaccine in patients with multiple sclerosis. Neurology 2013, 81, 552-558. [CrossRef] [PubMed]

102. Kappos, L.; Mehling, M.; Arroyo, R.; Izquierdo, G.; Selmaj, K.; Curovic-Perisic, V.; Keil, A.; Bijarnia, M.; Singh, A.; Von Rosenstiel, P. Randomized trial of vaccination in fingolimod-treated patients with multiple sclerosis. Neurology 2015, 84, 872-879. [CrossRef] [PubMed]

103. Mehta, L.; Umans, K.; Ozen, G.; Robinson, R.R.; Elkins, J. Immune Response to Seasonal Influenza Vaccine in Patients with Relapsing-Remitting Multiple Sclerosis Receiving Long-term Daclizumab Beta: A Prospective, Open-Label, Single-Arm Study. Int. J. MS Care 2017, 19, 141-147. [CrossRef] [PubMed]

104. Metze, C.; Winkelmann, A.; Loebermann, M.; Hecker, M.; Schweiger, B.; Reisinger, E.C.; Zettl, U.K. Immunogenicity and predictors of response to a single dose trivalent seasonal influenza vaccine in multiple sclerosis patients receiving disease-modifying therapies. CNS Neurosci. Ther. 2019, 25, 245-254. [CrossRef] [PubMed]

105. Olberg, H.K.; Cox, R.J.; Nostbakken, J.K.; Aarseth, J.H.; Vedeler, C.A.; Myhr, K.M. Immunotherapies influence the influenza vaccination response in multiple sclerosis patients: An explorative study. Mult. Scler. 2014, 20, 1074-1080. [CrossRef] [PubMed]

106. Olberg, H.K.; Eide, G.E.; Cox, R.J.; Jul-Larsen, A.; Lartey, S.L.; Vedeler, C.A.; Myhr, K.M. Antibody response to seasonal influenza vaccination in patients with multiple sclerosis receiving immunomodulatory therapy. Eur. J. Neurol. 2018, 25, 527-534. [CrossRef]

107. Von Hehn, C.; Howard, J.; Liu, S.; Meka, V.; Pultz, J.; Mehta, D.; Prada, C.; Ray, S.; Edwards, M.R.; Sheikh, S.I. Immune response to vaccines is maintained in patients treated with dimethyl fumarate. Neurol. Neuroimmunol. Neuroinflamm. 2018, 5, e409. [CrossRef]

108. McCarthy, C.L.; Tuohy, O.; Compston, D.A.; Kumararatne, D.S.; Coles, A.J.; Jones, J.L. Immune competence after alemtuzumab treatment of multiple sclerosis. Neurology 2013, 81, 872-876. [CrossRef]

109. Van Assen, S.; Holvast, A.; Benne, C.A.; Posthumus, M.D.; Van Leeuwen, M.A.; Voskuyl, A.E.; Blom, M.; Risselada, A.P.; De Haan, A.; Westra, J.; et al. Humoral responses after influenza vaccination are severely reduced in patients with rheumatoid arthritis treated with rituximab. Arthritis Rheum. 2010, 62, 75-81. [CrossRef]

110. Oren, S.; Mandelboim, M.; Braun-Moscovici, Y.; Paran, D.; Ablin, J.; Litinsky, I.; Comaneshter, D.; Levartovsky, D.; Mendelson, E.; Azar, R.; et al. Vaccination against influenza in patients with rheumatoid arthritis: The effect of rituximab on the humoral response. Ann. Rheum. Dis. 2008, 67, 937-941. [CrossRef]

111. Yri, O.E.; Torfoss, D.; Hungnes, O.; Tierens, A.; Waalen, K.; Nordoy, T.; Dudman, S.; Kilander, A.; Wader, K.F.; Ostenstad, B.; et al. Rituximab blocks protective serologic response to influenza A (H1N1) 2009 vaccination in lymphoma patients during or within 6 months after treatment. Blood 2011, 118, 6769-6771. [CrossRef] [PubMed] 
112. Kim, W.; Kim, S.H.; Huh, S.Y.; Kong, S.Y.; Choi, Y.J.; Cheong, H.J.; Kim, H.J. Reduced antibody formation after influenza vaccination in patients with neuromyelitis optica spectrum disorder treated with rituximab. Eur. J. Neurol. 2013, 20, 975-980. [CrossRef] [PubMed]

113. Zhang, J.; Medaer, R.; Stinissen, P.; Hafler, D.; Raus, J. MHC-restricted depletion of human myelin basic protein-reactive T cells by $\mathrm{T}$ cell vaccination. Science 1993, 261, 1451-1454. [CrossRef] [PubMed]

114. Medaer, R.; Stinissen, P.; Truyen, L.; Raus, J.; Zhang, J. Depletion of myelin-basic-protein autoreactive T cells by T-cell vaccination: Pilot trial in multiple sclerosis. Lancet 1995, 346, 807-808. [CrossRef]

115. Correale, J.; Lund, B.; McMillan, M.; Ko, D.Y.; McCarthy, K.; Weiner, L.P. T cell vaccination in secondary progressive multiple sclerosis. J. Neuroimmunol. 2000, 107, 130-139. [CrossRef]

116. Loftus, B.; Newsom, B.; Montgomery, M.; Von Gynz-Rekowski, K.; Riser, M.; Inman, S.; Garces, P.; Rill, D.; Zhang, J.; Williams, J.C. Autologous attenuated T-cell vaccine (Tovaxin) dose escalation in multiple sclerosis relapsing-remitting and secondary progressive patients nonresponsive to approved immunomodulatory therapies. Clin. Immunol. 2009, 131, 202-215. [CrossRef]

117. Fox, E.; Wynn, D.; Cohan, S.; Rill, D.; McGuire, D.; Markowitz, C. A randomized clinical trial of autologous T-cell therapy in multiple sclerosis: Subset analysis and implications for trial design. Mult. Scler. 2012, 18, 843-852. [CrossRef]

118. Bourdette, D.N.; Whitham, R.H.; Chou, Y.K.; Morrison, W.J.; Atherton, J.; Kenny, C.; Liefeld, D.; Hashim, G.A.; Offner, H.; Vandenbark, A.A. Immunity to TCR peptides in multiple sclerosis. I. Successful immunization of patients with synthetic V beta 5.2 and V beta 6.1 CDR2 peptides. J. Immunol. 1994, 152, 2510-2519.

119. Vandenbark, A.A.; Chou, Y.K.; Whitham, R.; Mass, M.; Buenafe, A.; Liefeld, D.; Kavanagh, D.; Cooper, S.; Hashim, G.A.; Offner, H. Treatment of multiple sclerosis with T-cell receptor peptides: Results of a double-blind pilot trial. Nat. Med. 1996, 2, 1109-1115. [CrossRef]

120. Bourdette, D.N.; Edmonds, E.; Smith, C.; Bowen, J.D.; Guttmann, C.R.; Nagy, Z.P.; Simon, J.; Whitham, R.; Lovera, J.; Yadav, V.; et al. A highly immunogenic trivalent $\mathrm{T}$ cell receptor peptide vaccine for multiple sclerosis. Mult. Scler. 2005, 11, 552-561. [CrossRef]

121. Vandenbark, A.A.; Culbertson, N.E.; Bartholomew, R.M.; Huan, J.; Agotsch, M.; LaTocha, D.; Yadav, V.; Mass, M.; Whitham, R.; Lovera, J.; et al. Therapeutic vaccination with a trivalent T-cell receptor (TCR) peptide vaccine restores deficient FoxP3 expression and TCR recognition in subjects with multiple sclerosis. Immunology 2008, 123, 66-78. [CrossRef]

122. Jurynczyk, M.; Walczak, A.; Jurewicz, A.; Jesionek-Kupnicka, D.; Szczepanik, M.; Selmaj, K. Immune regulation of multiple sclerosis by transdermally applied myelin peptides. Ann. Neurol. 2010, 68, 593-601. [CrossRef]

123. Walczak, A.; Siger, M.; Ciach, A.; Szczepanik, M.; Selmaj, K. Transdermal application of myelin peptides in multiple sclerosis treatment. JAMA Neurol. 2013, 70, 1105-1109. [CrossRef]

124. Belogurov, A., Jr.; Zakharov, K.; Lomakin, Y.; Surkov, K.; Avtushenko, S.; Kruglyakov, P.; Smirnov, I.; Makshakov, G.; Lockshin, C.; Gregoriadis, G.; et al. CD206-Targeted Liposomal Myelin Basic Protein Peptides in Patients with Multiple Sclerosis Resistant to First-Line Disease-Modifying Therapies: A First-in-Human, Proof-of-Concept Dose-Escalation Study. Neurotherapeutics 2016, 13, 895-904. [CrossRef]

125. Streeter, H.B.; Rigden, R.; Martin, K.F.; Scolding, N.J.; Wraith, D.C. Preclinical development and first-in-human study of ATX-MS-1467 for immunotherapy of MS. Neurol. Neuroimmunol. Neuroinflamm. 2015, 2, e93. [CrossRef] [PubMed]

126. Chataway, J.; Martin, K.; Barrell, K.; Sharrack, B.; Stolt, P.; Wraith, D.C.; Group, A.-M.S. Effects of ATX-MS-1467 immunotherapy over 16 weeks in relapsing multiple sclerosis. Neurology 2018. [CrossRef] [PubMed]

127. Fan, C.; Long, R.; You, Y.; Wang, J.; Yang, X.; Huang, S.; Sheng, Y.; Peng, X.; Liu, H.; Wang, Z.; et al. A novel PADRE-Kv1.3 vaccine effectively induces therapeutic antibodies and ameliorates experimental autoimmune encephalomyelitis in rats. Clin. Immunol. 2018, 193, 98-109. [CrossRef] [PubMed]

128. Beeton, C.; Wulff, H.; Standifer, N.E.; Azam, P.; Mullen, K.M.; Pennington, M.W.; Kolski-Andreaco, A.; Wei, E.; Grino, A.; Counts, D.R.; et al. Kv1.3 channels are a therapeutic target for T cell-mediated autoimmune diseases. Proc. Natl. Acad. Sci. USA 2006, 103, 17414-17419. [CrossRef] [PubMed]

129. Rus, H.; Pardo, C.A.; Hu, L.; Darrah, E.; Cudrici, C.; Niculescu, T.; Niculescu, F.; Mullen, K.M.; Allie, R.; Guo, L.; et al. The voltage-gated potassium channel Kv1.3 is highly expressed on inflammatory infiltrates in multiple sclerosis brain. Proc. Natl. Acad. Sci. USA 2005, 102, 11094-11099. [CrossRef] 
130. Zorzella-Pezavento, S.F.; Chiuso-Minicucci, F.; Franca, T.G.; Ishikawa, L.L.; da Rosa, L.C.; Colavite, P.M.; Balbino, B.; Marques, C.; Ikoma, M.R.; Masson, A.P.; et al. pVAXhsp65 Vaccination Primes for High IL-10 Production and Decreases Experimental Encephalomyelitis Severity. J. Immunol. Res. 2017, 2017, 6257958. [CrossRef]

131. Fissolo, N.; Montalban, X.; Comabella, M. DNA-based vaccines for multiple sclerosis: Current status and future directions. Clin. Immunol. 2012, 142, 76-83. [CrossRef] [PubMed]

132. Ruiz, P.J.; Garren, H.; Ruiz, I.U.; Hirschberg, D.L.; Nguyen, L.V.; Karpuj, M.V.; Cooper, M.T.; Mitchell, D.J.; Fathman, C.G.; Steinman, L. Suppressive immunization with DNA encoding a self-peptide prevents autoimmune disease: Modulation of T cell costimulation. J. Immunol. 1999, 162, 3336-3341. [PubMed]

133. Bar-Or, A.; Vollmer, T.; Antel, J.; Arnold, D.L.; Bodner, C.A.; Campagnolo, D.; Gianettoni, J.; Jalili, F.; Kachuck, N.; Lapierre, Y.; et al. Induction of antigen-specific tolerance in multiple sclerosis after immunization with DNA encoding myelin basic protein in a randomized, placebo-controlled phase 1/2 trial. Arch. Neurol. 2007, 64, 1407-1415. [CrossRef] [PubMed]

134. Garren, H.; Robinson, W.H.; Krasulova, E.; Havrdova, E.; Nadj, C.; Selmaj, K.; Losy, J.; Nadj, I.; Radue, E.W.; Kidd, B.A.; et al. Phase 2 trial of a DNA vaccine encoding myelin basic protein for multiple sclerosis. Ann. Neurol. 2008, 63, 611-620. [CrossRef] [PubMed]

135. Moore, P.A.; Belvedere, O.; Orr, A.; Pieri, K.; LaFleur, D.W.; Feng, P.; Soppet, D.; Charters, M.; Gentz, R.; Parmelee, D.; et al. BLyS: Member of the tumor necrosis factor family and B lymphocyte stimulator. Science 1999, 285, 260-263. [CrossRef] [PubMed]

136. Kappos, L.; Hartung, H.P.; Freedman, M.S.; Boyko, A.; Radu, E.W.; Mikol, D.D.; Lamarine, M.; Hyvert, Y.; Freudensprung, U.; Plitz, T.; et al. Atacicept in multiple sclerosis (ATAMS): A randomised, placebo-controlled, double-blind, phase 2 trial. Lancet Neurol. 2014, 13, 353-363. [CrossRef]

137. Xue, X.; Feng, G.; Li, M.; Qin, X.; Wu, S.; Zhang, C.; You, Y.; Wang, W.; Jiang, C.; Liu, Y.; et al. Amelioration of experimental autoimmune encephalomyelitis by BLyS autovaccine. Vaccine 2008, 26, 2873-2881. [CrossRef]

138. Rutschmann, O.T.; McCrory, D.C.; Matchar, D.B.; Immunization Panel of the Multiple Sclerosis Council for Clinical Practice Guidelines. Immunization and MS: A summary of published evidence and recommendations. Neurology 2002, 59, 1837-1843. [CrossRef]

139. Farez, M.F.; Correale, J.; Armstrong, M.J.; Rae-Grant, A.; Gloss, D.; Donley, D.; Holler-Managan, Y.; Kachuck, N.J.; Jeffery, D.; Beilman, M.; et al. Practice guideline update summary: Vaccine-preventable infections and immunization in multiple sclerosis: Report of the Guideline Development, Dissemination, and Implementation Subcommittee of the American Academy of Neurology. Neurology 2019. [CrossRef]

140. Lebrun, C.; Vukusic, S.; French Group for Recommendations in Multiple Sclerosis (France4MS); Societe Francophone de la Sclerose En Plaques (SFSEP). Immunization and multiple sclerosis: Recommendations from the French multiple sclerosis society. Mult. Scler. Relat. Disord. 2019, 31, 173-188. [CrossRef]

141. Furer, V.; Rondaan, C.; Heijstek, M.W.; Agmon-Levin, N.; van Assen, S.; Bijl, M.; Breedveld, F.C.; D’Amelio, R.; Dougados, M.; Kapetanovic, M.C.; et al. 2019 update of EULAR recommendations for vaccination in adult patients with autoimmune inflammatory rheumatic diseases. Ann. Rheum. Dis. 2020, 79, 39-52. [CrossRef] [PubMed]

(C) 2020 by the authors. Licensee MDPI, Basel, Switzerland. This article is an open access article distributed under the terms and conditions of the Creative Commons Attribution (CC BY) license (http://creativecommons.org/licenses/by/4.0/). 